\title{
Uroptychodes, new genus of Chirostylidae (Crustacea: Decapoda: Anomura), with description of three new species*
}

\author{
KEIJI BABA \\ Faculty of Education, Kumamoto University, 2-40-1 Kurokami, Kumamoto 860-8555, Japan. \\ E-mail: keiji@gpo.kumamoto-u.ac.jp
}

\begin{abstract}
SUMMARY: Examination of materials collected from Indonesia, New Caledonia and vicinity, now deposited in the Muséum National d'Histoire Naturelle, disclosed three additional undescribed species of chirostylids belonging to the Uroptychus spinimarginatus group. The group is now shifted to a distinct genus Uroptychodes. Uroptychus grandirostris Yokoya, 1933, which can be transferred to Uroptychodes, has been a problematic species because of the brevity of the original description and the loss of the type material. However, a recent finding of a specimen, which is in poor condition, very much like the illustration of $U$. grandirostris by Yokoya (1933: Fig. 29), but different from the description of $U$. grandirostris given by van Dam (1939) for one of the type specimens, suggests that the type material of $U$. grandirostris includes at least two species. In this paper a neotype is selected for $U$. grandirostris. The genus Uroptychodes now contains 10 species. All these species are reviewed and a key to the species of the genus is provided.
\end{abstract}

Key words: Crustacea, Decapoda, Chirostylidae, Uroptychodes, new genus, systematics.

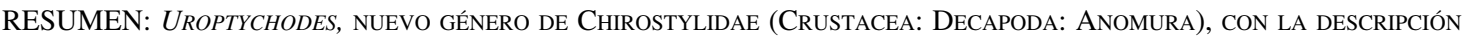
DE TRES NUEVAS ESPECIES. - El examen de material recolectado en Indonesia, Nueva Caledonia y alrededores, en la actualidad depositado en el Museum national d'Histoire Naturelle, ha permitido detectar la presencia de tres especies de quirostílidos no descritas, pertenecientes al grupo Uroptychus spinimarginatus. El grupo se transfiere ahora al género diferenciado Uroptychodes. Uroptychus grandirostris Yokoya, 1933, que puede ser transferido a Uroptychodes, ha sido una especie problemática debido a la brevedad de la descripción original y a la pérdida del material tipo. No obstante, el reciente hallazgo de un espécimen, en deficientes condiciones, que se asemeja mucho a la ilustración de U. grandirostris de Yokoya (1933: fig. 29), pero difiere de la descripción de $U$. grandirostris dada por van Dam (1939) para uno de los especímenes tipo, sugiere que el material tipo de $U$. grandirostris incluye por lo menos, dos especies. En este trabajo se selecciona un neotipo para $U$. grandirostris. El género Uroptychodes contiene ahora 10 especies. Se hace una revisión de todas ellas y se presenta una clave para las especies del género.

Palabras clave: Crustacea, Decapoda, Chirostylidae, Uroptychodes, género nuevo, sistemática.

\section{INTRODUCTION}

The Uroptychus spinimarginatus group, first recognised by Baba (1977), is an aberrant group in Uroptychus characterised by an elongate, ventrally

*Received May 9, 2003. Accepted July 25, 2003. carinate rostrum and very slender second pereopods with an unarmed dactylus, distinctive characters that can be used to separate it from the other species of Uroptychus. This group is shifted to a new genus Uroptychodes in this paper. The systematic status of Uroptychus grandirostris Yokoya, 1933, which should be transferred to the new genus, has 
remained uncertain due to its brief description. Van Dam (1939) redescribed $U$. grandirostris based on part of the type material. Her description is detailed, but the lateral marginal spines of the carapace are shown as much broader than originally defined. Recently, a specimen found in the collection made by the late S. Miyake and now in the Kitakyushu Museum of Natural History, Japan, came to my attention. It is in poor condition, leaving the carapace, sternal plastron, part of the third maxilliped, and cheliped visible, but other portions are almost damaged. The characters displayed by this specimen are not sufficient to determine its systematic status, but suggest that it fits the brief definition given by Yokoya (1933) or could be referable to $U$. albatrossae Baba, 1988, differing from the material examined by van Dam (1939). This fact suggests that the type material of Yokoya, which was collected from seven different localities in Japan, contains at least two species. Because the type material of $U$. grandirostris is no longer extant and because the specimen used by van Dam (1939) could not be located, a neotype that fits van Dam's description was chosen for $U$. grandirostris.

In addition, three new species referable to Uroptychodes were found in collections made by recent surveys around Indonesia (Karubar) and New Caledonia and its vicinity (BIOCAL, MUSORSTOM 4, VOLSMAR, BERYX 11, BATHUS 3, HALIPRO 1) (Crosnier et al., 1997; Richer de Forges, 1990, 1993; Richer de Forges \& Chevillon, 1996). The genus now contains 10 species: $U$. albatrossae (Baba, 1988), $U$. barunae sp. nov., U. benedicti (Baba, 1977), U. epigater sp. nov., U. grandirostris (Yokoya, 1933), U. mortenseni (van Dam, 1939), U. musorstomi sp. nov., U. okutanii (Baba, 1981), U. spinimarginatus (Henderson, 1885), and U. spinulifer (van Dam, 1940).

\section{TERMINOLOGY AND MEASUREMENTS}

The term "sternite(s)" used in the text is restricted to "thoracic sternite(s)". The thoracic sternites in the Chirostylidae are composed largely of two parts. The posterior part is the so-called "sternal plastron" or "thoracic sternum" (Tirmizi, 1964; McLaughlin, 1980), providing insertions of third maxillipeds and first to fourth pereopods; there is no sternal plate for the last somite of the thorax in the Chirostylidae (Balss, 1957; Baba, 1990). No attention has been paid to the anterior part: it is depressed or excavated in ventral view from the level of the sternal plastron in order to accommodate distal segments of the third maxillipeds when folded. When the third maxillipeds are extended forward, this part and corresponding appendages, the first to third maxillipeds, are visible by careful examination in a ventral aspect. Apparently, the third maxillipeds arise from the excavated part directly adjacent to the anterior-most part of the sternal plastron. This means that the anterior-most margin of the sternal plastron does not represent the true anterior margin of the third thoracic sternite. In this paper, the anterior part of the thoracic sternites is called the "excavated sternum," the posterior part is the "sternal plastron," and each sternite constituting the sternal plastron is named "sternite 3 (corresponding to the third maxillipeds)", "sternite 4 (corresponding to the first pereopods)", etc.

The measurements given under "Material examined" indicate postorbital carapace length, a distance between the front and posterior margins of the carapace in midline.

The abbreviations used in the text include: Mxp $=$ maxilliped $; \mathrm{P}=$ pereopod BM $=$ Natural History Museum, London; MNHN = Muséum National d'Histoire Naturelle, Paris; NSMT = National Science Museum, Tokyo; USNM = National Museum of Natural History, Washington, D.C; ZLKU = Kitakyushu Museum of Natural History (formerly registered under Zoological Laboratory, Kyushu University); ZMA = Zoological Museum, Amsterdam; ZMUC = Zoological Museum, University of Copenhagen.

Most of the material here reported is deposited in the Muséum National d'Histoire Naturelle, Paris, and part will be in the collection of the Smithsonian Institution, Washington D.C.

\section{SYSTEMATICS}

Order DECAPODA Latreille, 1802

Infraorder ANOMURA H. Milne Edwards, 1832

Family CHIROSTYLIDAE Ortmann, 1892

Uroptychodes gen. nov.

Diagnosis: Body and appendages usually covered with fine setae. Carapace armed with row of lateral spines. Rostrum basally broad but elongate, often more than length of remaining carapace, ventral surface carinate in midline. Excavated sternum bearing longitudinal ridge in midline. Cornea usually not fully visible from above. Antennal flagellum very short, not extending beyond end of rostrum. 
Mxp 3 ischium with distinct spine lateral to rounded flexor distal margin. P1 relatively slender, spinose or covered with denticular small spines. P2 definitely more slender than P3 and P4, dactylus usually unarmed on flexor margin; carpus longer than that of P3. P3-4 having dactyli with row of spines on flexor margin, penultimate usually pronounced; carpus much shorter relative to that of $\mathrm{P} 2$, about half as long as propodus.

Type species: Uroptychodes epigaster sp. nov.
Remarks: The new genus is separated from Uroptychus by the very elongate and ventrally carinate rostrum and P2 more slender than P3-4, having the carpus distinctly longer than those of P3-4 and the dactylus entire on the flexor margin.

Among members of Uroptychus is another aberrant form, U. naso van Dam, 1933, which possesses most of the characters with Uroptychodes. However, it is distinctive in that the $\mathrm{P} 2$ is similar to $\mathrm{P} 3$ and $\mathrm{P} 4$, having the dactylus with a row of spines on the flexor margin, a character shared by Uroptychus.
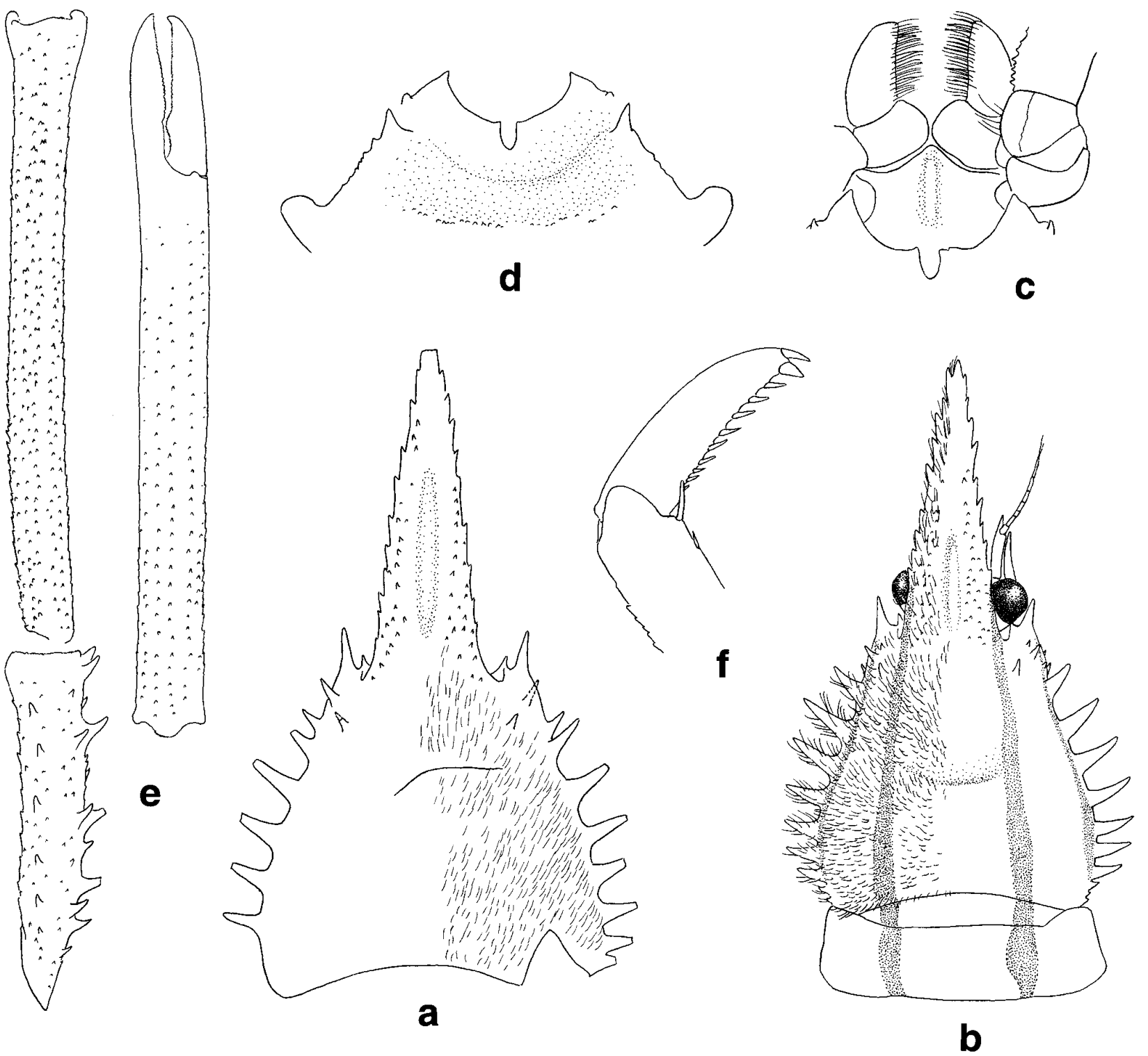

1 2 3 4

FIG. 1. - Uroptychodes albatrossae (Baba, 1988); a, c, e, male (ZLKU 4881); b, d, female (MNHN Ga-4164); f, ovigerous female (MNHN Ga-4197): a, carapace, setae omitted on left half, dorsal; b, same, setae omitted from right half of carapace and whole abdomen, dorsal; c, excavated sternum and anterior part of sternal plastron, parts of Mxps included, ventral; d, anterior part of sternal plastron, ventral; e, left P1, dorsal; f, distal part of right P3, lateral. Scales $=1 \mathrm{~mm}$; scale 1 for b, e; scale 2 for a; scale 3 for d; scale 4 for c, f. 
Etymology: From Uroptychus and the Greek suffix odes (resembling). The gender is masculine.

\section{Uroptychodes albatrossae (Baba, 1988)}

(Fig. 1)

Uroptychus albatrossae Baba, 1988: 22, Fig. 8.

Holotype: Ovigerous female, USNM 150302, off northern Mindanao, $8^{\circ} 47^{\prime} \mathrm{N}, 123^{\circ} 31^{\prime} 15^{\prime \prime} \mathrm{E}, 333 \mathrm{~m}$.

Material examined: Japan. Off Nanbu, Kii Peninsula, Mar. 1943, S. Sakaguchi coll.: 1 o (ZLKU 4881). Tanimbar Island, Indonesia; KARUBAR: $\operatorname{stn} 50,7^{\circ} 59^{\prime} \mathrm{S}, 1^{\circ} 3^{\circ} 02^{\prime} \mathrm{E}, 184-186$ m, 29 Oct. 1991: 1

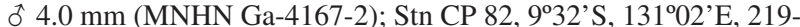
215 m, 4 Nov. 1991: 1 क 4.5 mm (MNHN Ga-4164); Stn CP 86, 9²6'S, 131 13' $13^{\prime} \mathrm{E}, 225-223 \mathrm{~m}, 4$ Nov. 1991: 1 ov. क $3.8 \mathrm{~mm}$ (MNHN Ga-4197).

Diagnosis: Carapace laterally with well-developed anterolateral spine followed by a few small spines and again 8 strong spines, last usually much smaller and occasionally followed by 1 or 2 additional small spines. Hepatic region usually with 2 spines, occasionally with additional few spinules. Rostrum more or less deflexed, dorsal surface well excavated longitudinally, bearing tubercular spines laterally; lateral margin with 9-12 (15 in type) small spines. Excavated sternum anteriorly wide, triangular, surface bearing ridge in midline on anterior half. Abdomen spineless, covered with fine setae. Antennal peduncles with strong distoventral spine on each of distal 2 segments; antennal scale nearly or barely reaching end of ultimate segment; flagellum consisting of 7-8 segments, not reaching end of rostrum. Mxp 1 having basal segment strongly convex mesially and nearly contiguous. Mxp 3 ischium with obsolescent denticles on mesial ridge; distolateral spine on merus and carpus well developed; merus with 3 or 4 denticular spines on flexor margin. Pereopods (excepting P5) covered with denticular spines (not on distal segment). P1 merus with well-developed spines; merus and carpus covered with tubercular spines. P2 merus with row of 6-7 sharp spines rather distant from one another on extensor margin; carpus slightly shorter than propodus $(0.90$ 0.94 times as long). P3-4 meri with 6-7 extensor marginal spines stronger than those on $\mathrm{P} 2$; propodi with tubercular spines along extensor margin and even on surface lateral and mesial to it, flexor margin ending in pair of spines preceded by 0 or 1 spine; dactyli ending in slender spine (ultimate) preceded by much wider and slightly shorter spine (penultimate) and 9-10 slender, proximally diminishing spines.
Eggs: Eggs carried up to 20 in number, measuring $1.0-1.1 \mathrm{~mm}$ in diameter.

Remarks: In the ovigerous female (MNHN Ga4197), two narrow longitudinal stripes of pale orange are visible on the carapace and abdomen (Fig. 1b).

The male specimen from Japan (ZLKU 4881) is broken but the carapace, sternal plastron, and P1, the only characters left visible, suggest that it is referable to $U$. albatrossae (Baba, 1988). This specimen is also very much like the illustration of $U$. grandirostris provided by Yokoya (1933). More about this specimen is discussed under $U$. grandirostris (see below).

Range: Japan off Kii Peninsula, Philippines off northern Mindanao, between Negros and Siquijor, between Cebu and Bohol, and Indonesia around Tanimbar Island; 184-510 m.

Uroptychodes barunae sp. nov. (Figs. 2, 3)

Material examined: Tanimbar Island, Indonesia; KARUBAR: stn DW 49, 800'S, 13259'E, 210-206 m, 29 Oct. 1991: 1 ô 2.4 mm (MNHN Ga-4170). Stn 50, $7^{\circ} 59^{\prime} \mathrm{S}, 133^{\circ} 02^{\prime} \mathrm{E}, 184-186$ m, 29 Oct. 1991: 1 ov. ㅇ $5.0 \mathrm{~mm}$, holotype (MNHN Ga-4167-1).

Description: Body covered with short fine setae in larger specimen, less setose in smaller specimen. Carapace relatively long, slightly shorter than wide, dorsally with distinct groove posterior to midlength, separating anterior and posterior regions; hepatic region with mesially converging row of three spines directly behind anterolateral spine, last spine larger; a few additional small spines in larger specimen. Lateral margin having slender anterolateral spine followed by about 7 spines (distinctly larger than anterolateral spine) along entire length of branchial margin; in larger specimen, another row of small spines present between linea anomurica and lateral marginal spines. Rostrum nearly as long as remaining carapace, longitudinally hollowed, lateral margin with 5-6 spines.

Pterygostomian flap with acute spine at anterior end, surface covered with small spines moderate in density.

Excavated sternum anteriorly wide, triangular, ending in blunt but well-produced process or spine; surface bearing longitudinal ridge in midline on anterior half. Sternite 3 well depressed, anterior margin well excavated, with semicircular or U- 

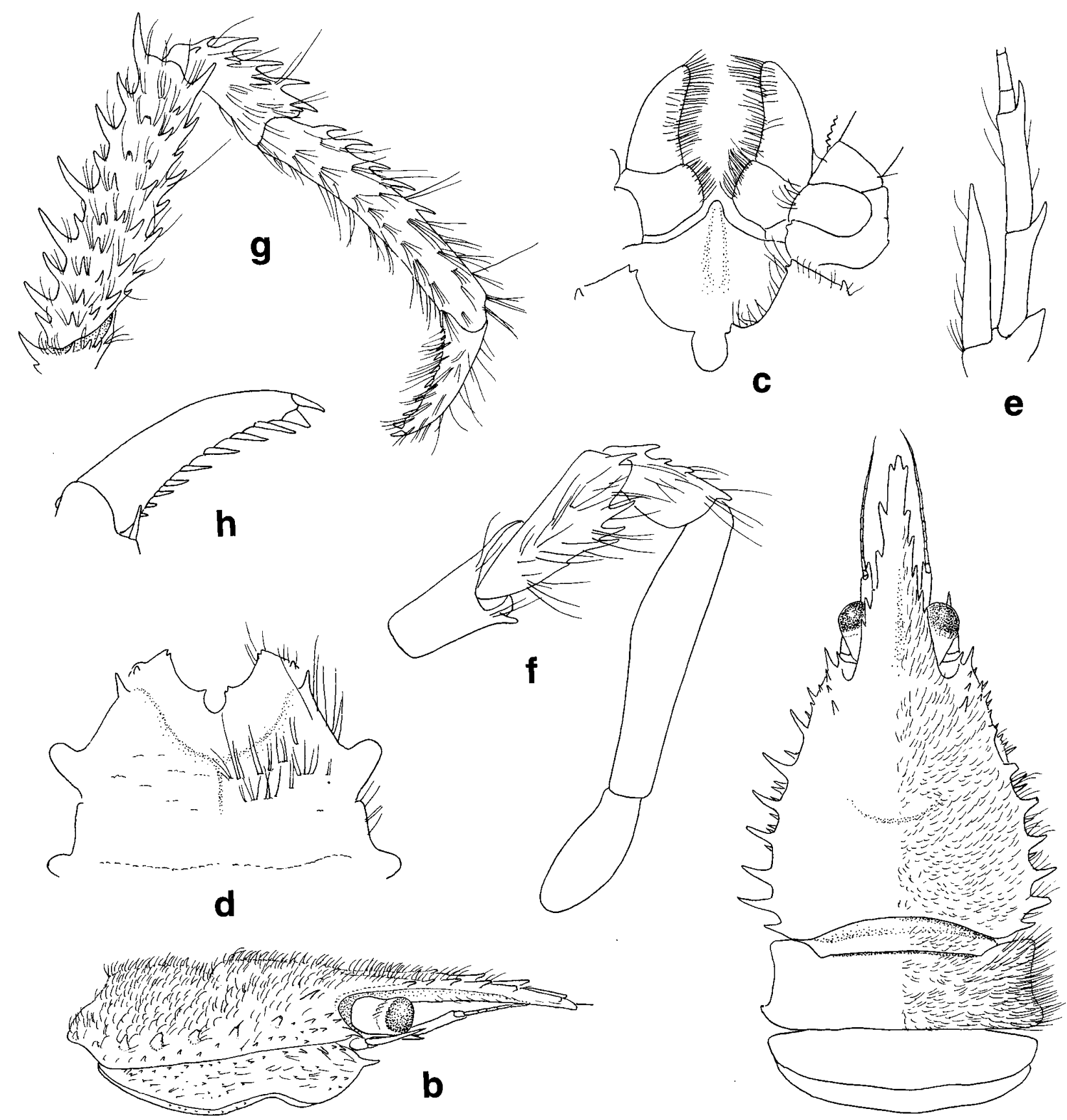

a

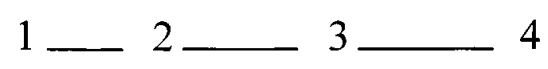

5

6

7

FIG. 2. - Uroptychodes barunae sp. nov., ovigerous female holotype (MNHN Ga-4167): a, carapace and anterior part of abdomen (denuded on left half of carapace and first and second abdominal somites and whole third and fourth abdominal somites), dorsal; b, same, abdomen omitted, lateral; c, excavated sternum and anterior part of sternal plastron, parts of Mxps included, ventral; d, anterior part of sternal plastron, ventral; e, right antennal peduncle, ventral; f, endopod of right Mxp 3, setae omitted from distal segments, lateral; g, right P4, lateral; h, distal part of same, setae omitted, lateral. Scales $=1 \mathrm{~mm}$; scale 1 for a, b; scale 2 for g; scale 3 for d; scale 4 for f; scale 5 for e; scale 6 for h; scale 7 for $\mathrm{c}$.

shaped notch flanked by small spine; Sternite 4 having anterolateral corner ending in anterolaterally directed, small, sharp spine.

Abdomen unarmed, covered with setae more thickly in larger specimen.
Antennal peduncles relatively slender, ultimate and penultimate segments each armed with strong distoventral spine; antennal scale extending beyond cornea, slightly exceeding beyond penultimate segment or ending in mid-length of ultimate segment; 

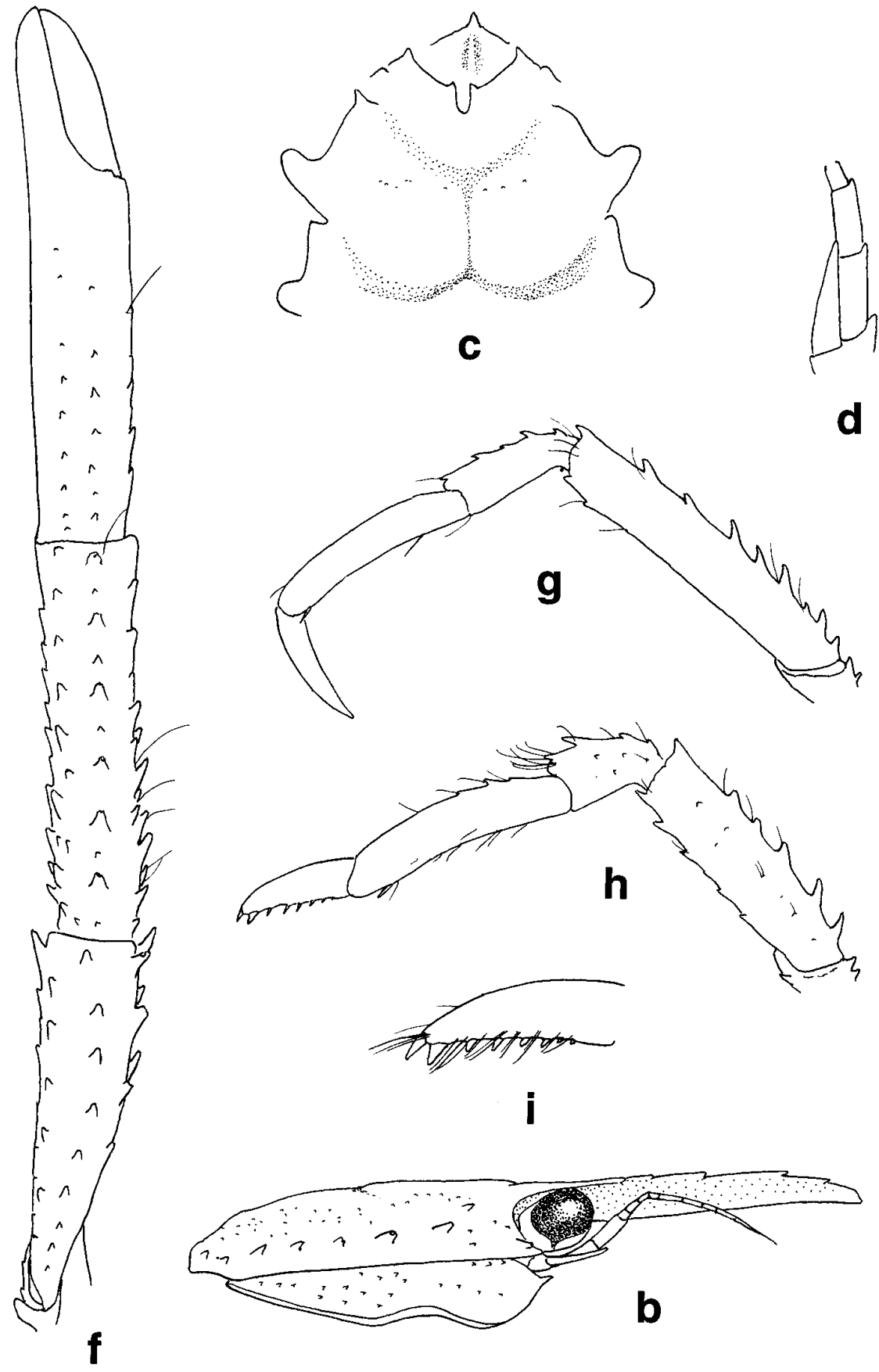

1

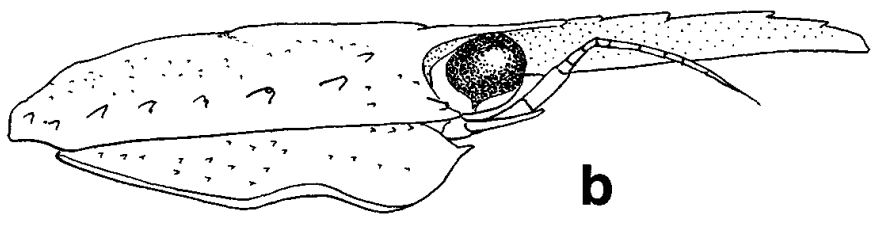

2

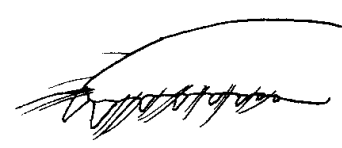

i

FIG. 3. - Uroptychodes barunae sp. nov., male paratype (MHNH Ga-4170): a, carapace and anterior part of abdomen, setae and their pits omitted on right half, dorsal; b, same, abdomen omitted, lateral; c, excavated sternum and anterior part of sternal plastron, ventral; d, right antennal peduncle, ventral; e, endopod of right Mxp 3, distal segments omitted, lateral; f, left P1, dorsal; g, left P2, lateral; h, left P3, lateral; i, distal segment of same, lateral. Scales $=1 \mathrm{~mm}$; scale 1 for a, $\mathrm{b}$; scale 2 for $\mathrm{f}$, g, h; scale 3 for c; scale 4 for d, e; scale 5 for i.

flagellum consisting of 11 segments, slightly overreaching rostral tip in large specimen, 7 segments, not reaching end of rostrum in small specimen.

Mxps 1 widely separated. Mxp 3 relatively slender. Ischium with distinct distal spine lateral to flex-

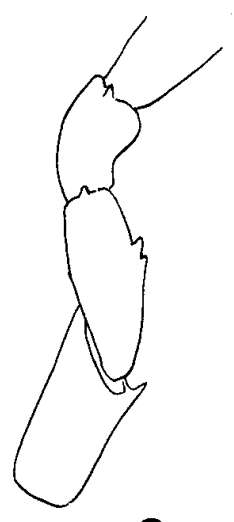

e

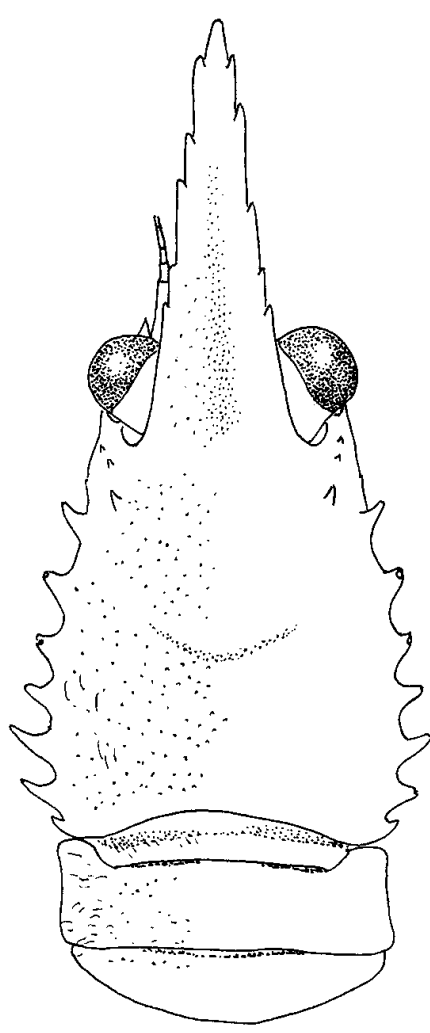

a or distal margin, mesial ridge with 26 denticles. Merus elongate, with well developed distolateral spine and 2 or 3 similar spines distal to mid-length of flexor margin. Carpus distolaterally ending in strong spine as large as that of merus, preceded by 2 
or 3 spines. Coxa with 2 spines ventrally. Basis with 4 denticles on mesial ridge.

Left P1 in small specimen available; sparingly setose; 4 times as long as carapace. Merus with 7 rows of distinct spines ( 2 dorsal, 1 lateral, 2 mesial, 2 ventral) continued onto carpus, and even on proximal portion of palm.

Smaller specimen having P2-3 sparingly setose. P2 having carpus about half as long as propodus; merus and carpus with relatively sharp spines on flexor margin; propodus unarmed except for distal pair of spines on flexor margin; dactylus longer than carpus. P3 somewhat wider tan P2; meral and carpal spinations nearly as same as those of $\mathrm{P} 2$, but extensor margin of merus with row of spines; propodus with 3 extensor marginal spines proximally, flexor margin ending in pair of spines without preceding spine; dactylus half as long as propodus, flexor mar- gin nearly straight, ultimate spine somewhat narrower than largest penultimate preceded by $6-8$ successively diminishing slender spines.

Larger specimen with $\mathrm{P} 4$ only; very setose. Meral, carpal and propodal spines more sharp and stronger than on $\mathrm{P} 2-3$; propodus with 1 spine proximal to distal pair on flexor margin; dactylus distally narrowed, ultimate spine nearly as large as antepenultimate, penultimate widest, shorter than ultimate and antepenultimate.

Eggs: Number of eggs carried, 16; diameter, $1.1 \mathrm{~mm}$.

Remarks: This species is very close to $U$. albatrossae in the carapace spination, and one of the specimens was found in a lot that includes a specimen of the latter. However, I am inclined to believe that these two species are separated by the following
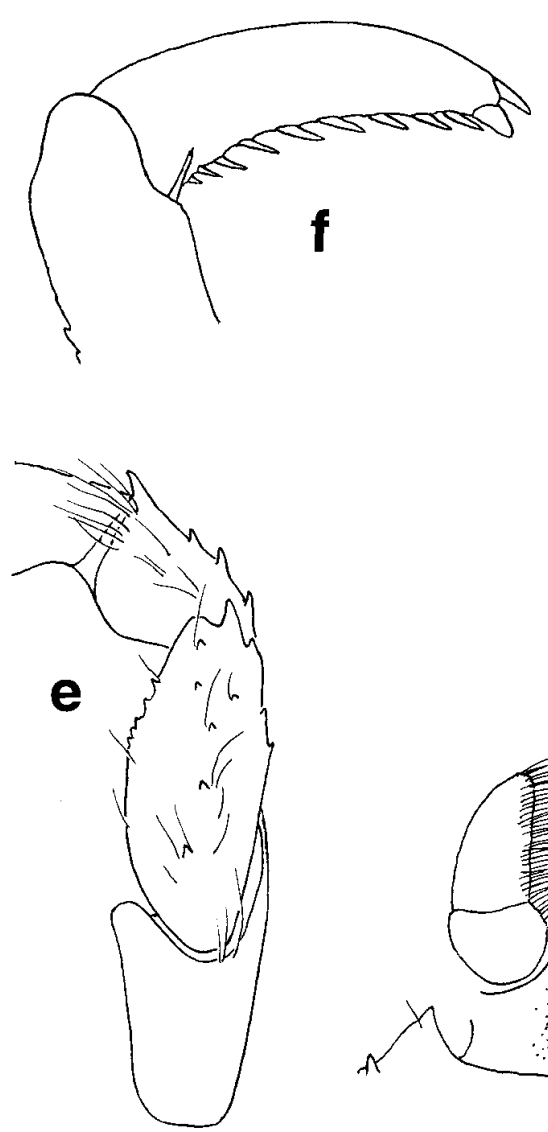

1

$-2$

FIG. 4. - Uroptychodes benedicti (Baba, 1977); a, d, e, f, ovigerous female (MNHN Ga-4166); b, c, male (MNHN Ga-4169): a, carapace and anterior part ofabdomen; $b$, anterolateral part of carapace, left, dorsal; c, same, slightly dorsolateral; d, excavated sternum and anterior part of sternal plastron, parts of Mxps included; e, endopod of left Mxp 3, distal segments omitted, lateral; f, distal part of right P3, lateral. Scales

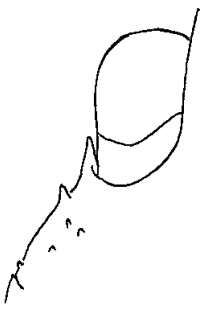

C

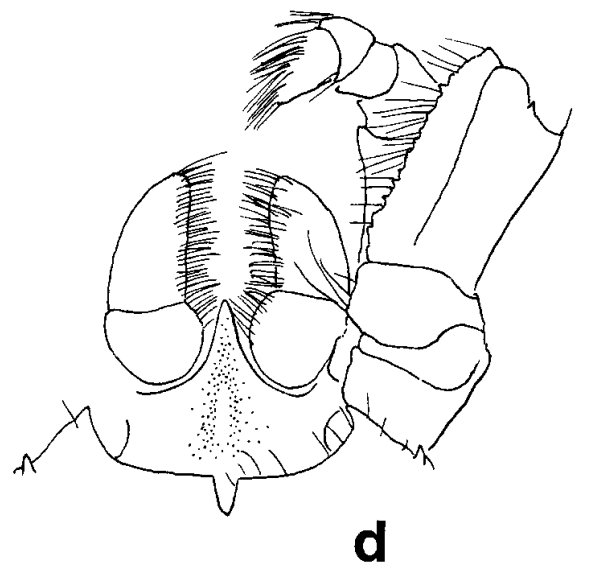

3
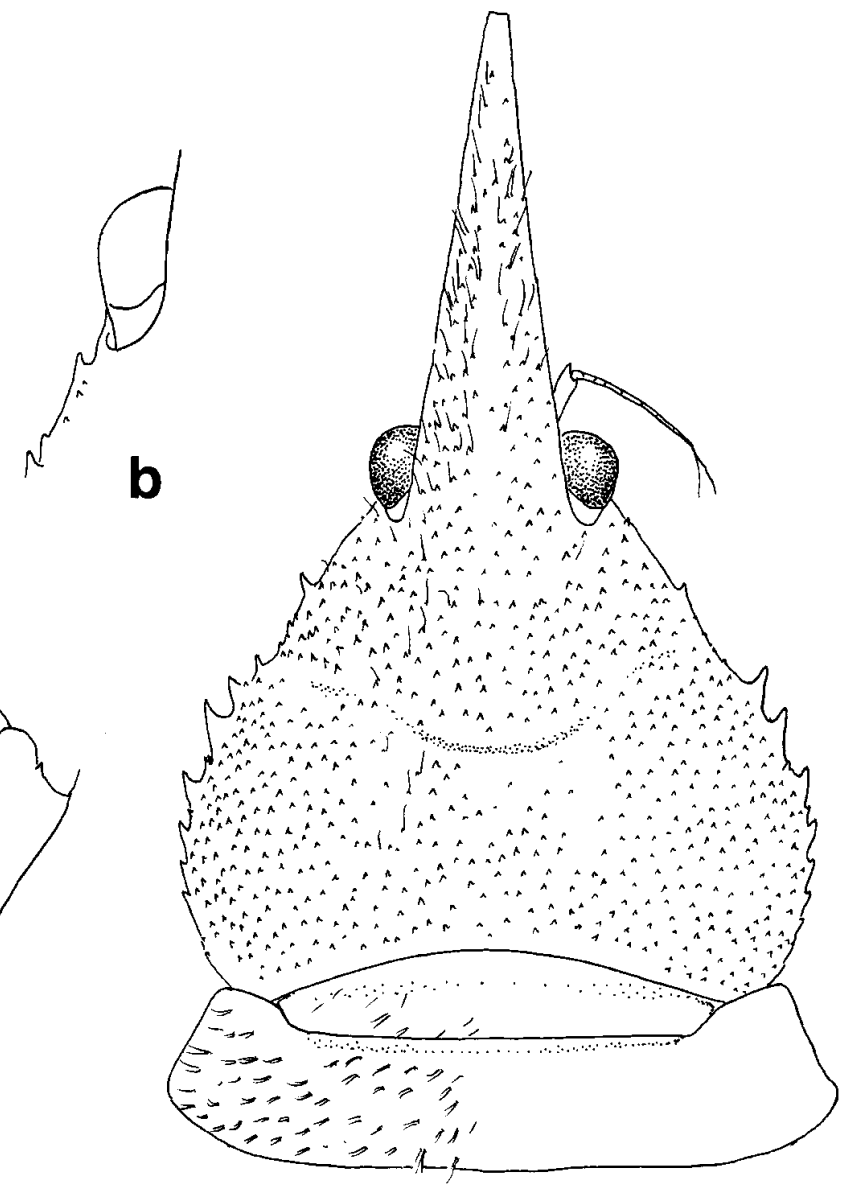

a

$$
=1 \mathrm{~mm} \text {; scale } 1 \text { for a; scale } 2 \text { for } \mathrm{f} \text {; scale } 3 \text { for } \mathrm{b} \text {-e. }
$$


differences: the rostral lateral spines in the new species are much fewer, 5-6 in the new species, 9-12 in $U$. albatrossae; the antennal scale is reaching at most the mid-length of the ultimate peduncular segment in the new species, instead of reaching the end of that segment in $U$. albatrossae; Mxps 1 are more distantly separated from each other in the new species, whereas they are close between the basal segments in $U$. albatrossae; $\mathrm{P} 2-4$ bear more prominent spines on the merus, carpus and propodus in the new species than in $U$. albatrossae.

Etymology: Named for the R/V "Baruna Jaya 1" by which the material was collected.

\section{Uroptychodes benedicti (Baba, 1977)}

(Fig. 4)

Uroptychus benedicti Baba, 1977: 123, Fig. 1.

Holotype: Male, USNM 150307, off Omae-zaki Light, Honshu, Japan; 34 fms (62 m).

Material examined: Kai Islands, Indonesia; KARUBAR: stn DW 22, 5'22' $\mathrm{S}, 133^{\circ} 01^{\prime} \mathrm{E}, 124-850 \mathrm{~m}, 25$ Oct. 1991: 1 ô $2.1 \mathrm{~mm}$ (MNHN Ga-4169). Tanimbar Island, Indonesia; KARUBAR: stn DW 50, 759'S, $133^{\circ} 02^{\prime} \mathrm{E}, 184-186 \mathrm{~m}, 29$ Oct. 1991: 1 ov. 93.5 mm (MNHN Ga-4166).

Diagnosis: Body covered with short fine setae. Carapace strongly widened posteriorly, covered with small denticular spines. Lateral margins convex on posterior two-thirds, bearing about 7 spines of small but irregular sizes on branchial region; lateral orbital spine substituting anterolateral spine, strongly produced; small but distinct spine equidistant between anterolateral spine and first of branchial marginal spines. Rostrum straight, horizontal, lacking lateral spines, length more than carapace length. Excavated sternum anteriorly ending in strong process fully reaching end of basal segment of Mxp 1, surface cristate in midline; sternite 3 shallowly depressed, anterior margin shallowly excavated, bearing small Vshaped median notch. Abdomen spineless, covered with short fine setae. Antennal peduncles having distal 2 segments each armed with strong distoventral spine; antennal scale terminating in end of penultimate segment; flagellum short, consisting of 7 segments. Mxps 1 separated. Mxp 3 ischium with small rather obsolescent denticles on mesial ridge, distal margin with very small spine lateral to rounded distal lobe on flexor face; merus ending in strong distolateral spine, flexor margin with several denticles distal to midlength, extensor margin with a few very small spines on distal half, lateral surface also with small denticular spines roughly in longitudinal row; carpus with a few exten- sor marginal spines and strong distolateral spine. P1 covered with tubercular small spines; merus with 3 rows of large spines (1 mesial, 1 mesiodorsal, 1 mesioventral). P2-4 covered with tubercular small spines except for distal segment, meral flexor marginal spines distinctly larger. P2 distinctly more slender than P3-4, carpus longer than propodus; dactylus entire on flexor margin. P3-4 propodi ending in pair of spines without preceding spine; dactyli ending in slender spine preceded by broad penultimate spine and other 9-10 proximally diminishing slender spines, antepenultimate as large as ultimate.

Eggs: Four eggs carried but normal number probably more; $1.2 \mathrm{~mm}$ in diameter.

Remarks: In the ovigerous female, denticular spines on the carapace and pereopods are set as in the type, but in the male, which is somewhat smaller than the male holotype, denticular spines are distinct only along the lateral margin of the carapace, barely discernible elsewhere. The propodus of the P2 is about as long as the carpus in the small specimens, including the type and the male examined, while in the large female it is shorter than the carpus (the length ratio being 26:36), longer than the dactylus (31/23).

The lateral limit of the orbit is produced into a strong spine, which is barely discernible in a dorsal aspect but apparent in a dorsolateral view (Fig. 4b, c), a useful character to separate the species from the others.

The excavated sternum represents a unique shape among the members of the genus, the anteromedian process extending as far forward as the distal end of the basal segment of Mxp 1.

Range: Previously known from Japan off Omaezaki, Honshu in $62 \mathrm{~m}$. The male from Indonesia is recorded between 124 and $850 \mathrm{~m}$, and the female is between 184 and $186 \mathrm{~m}$.

\section{Uroptychodes epigaster sp. nov.} (Fig. 5)

Material examined: New Caledonia; BIOCAL: stn DW 51, 2305' S, 167²4'E, 680-700 m, 31 Aug. 1985: 1 ㅇ $3.7 \mathrm{~mm}$,

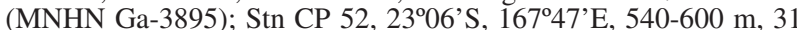
Aug. 1985: 1 क $4.3 \mathrm{~mm}, 2$ ov. ㅇ 4.2, $4.3 \mathrm{~mm}$ (MNHN Ga-4580). MUSORSTOM 4: stn DW 222, 22 $57.6^{\prime} \mathrm{S}, 17^{\circ} 33.0^{\prime} \mathrm{E}, 410-440 \mathrm{~m}$, 30 Sept. 1985: 1 q $5.6 \mathrm{~mm}$, holotype (MNHN Ga-4581). BERYX 11: stn DW $38,23^{\circ} 37.53^{\prime} \mathrm{S}, 1^{\circ} 7^{\circ} 39.42^{\prime} \mathrm{E}, 550-690 \mathrm{~m}, 19$ Oct 1992 1 ov. $4.8 \mathrm{~mm}$ (MNHN Ga-3846)

Types: The female from Musorstom 4 : stn DW 222 (MNHN Ga4581 ) is selected as the holotype, the other specimens are paratypes. 


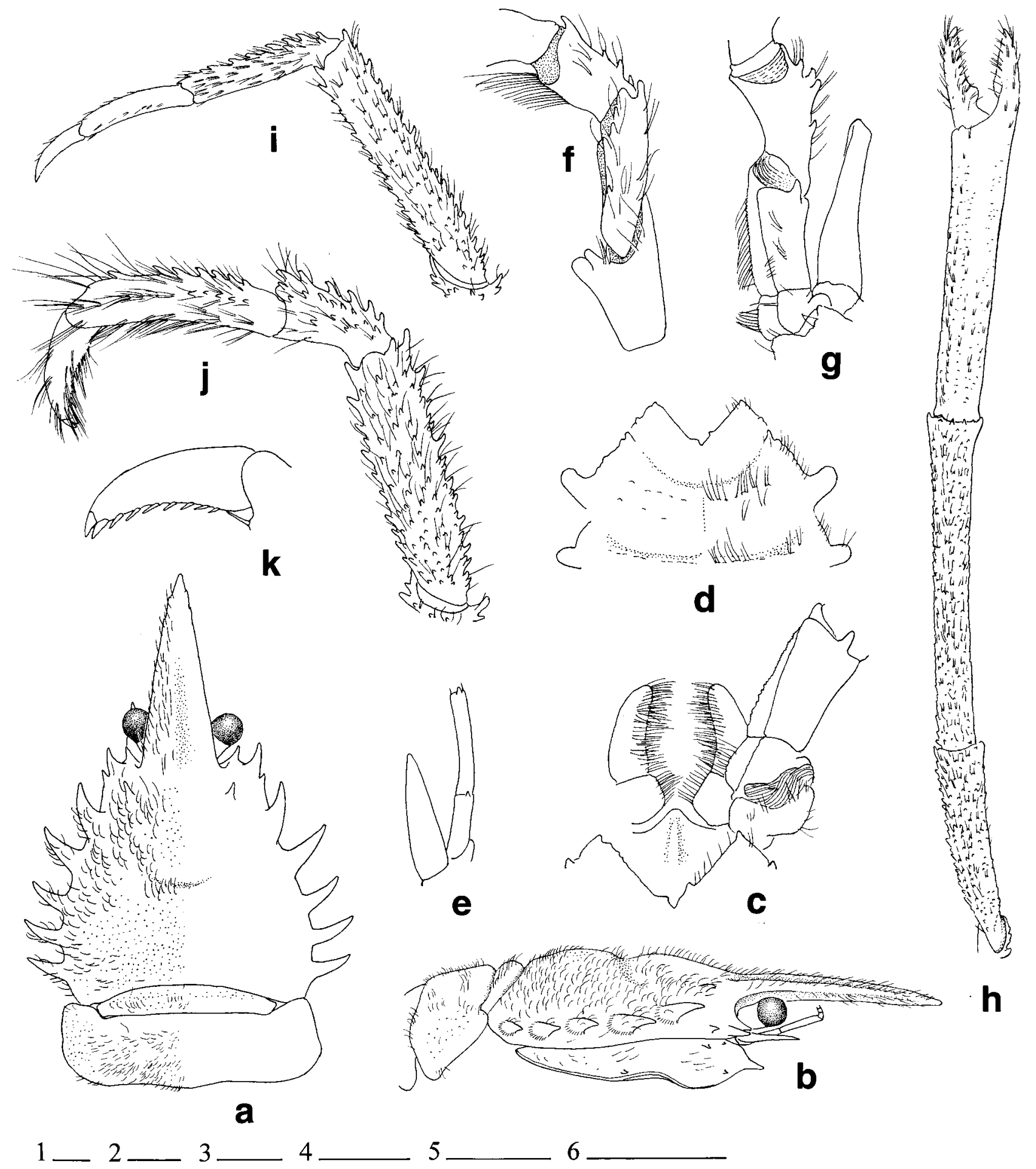

FIG. 5. - Uroptychodes epigaster sp. nov., female holotype (MNHN Ga- 4581): a, carapace and anterior part of abdomen, setae omitted from right half, dorsal; b, same, lateral; c, excavated sternum and anterior part of sternal plastron, parts of Mxps included, ventral; $d$, anterior part of sternal plastron, ventral; e, right antennal peduncle, ventral; f, endopod of left Mxp 3, distal segments omitted, lateral; g, same, ventral; h, right P1, dorsal; i, left P2, lateral; j, left P3, lateral; k, distal part of same, setae omitted. Scales 1-5=1 mm; scale $6=5 \mathrm{~mm}$; scale 1 for a, $\mathrm{b}$; scale 2 for $\mathrm{i}, \mathrm{j}$; scale 3 for c; scale 4 for e, f, g, k; scale 5 for d; scale 6 for $\mathrm{h}$.

Description: Carapace covered with more or less stiff setae moderate in density. Lateral margins convexly divergent; well-developed anterolateral spine followed behind by small spine often obsolete or even absent, and other 5 very strong sharp spines on branchial region, anterior-most distinctly dorsal to level of remainder. Pair of spines each located behind lateral limit of orbit. Rostrum horizontal, 
about as long as or slightly shorter than remaining carapace, lateral margin with a few distal spines; dorsal surface excavated.

Pterygostomian flap anteriorly ending in acute spine, surface with a number of spines around midline and 2 directly under anterior linea anomurica.

Excavated sternum anteriorly produced, subtriangular, ending in blunt tip; surface with ridge in midline on anterior half. Sternite 3 having anterior margin nearly V-shaped, with median notch flanked by small spine.

Abdomen setose like carapace, unarmed.

Antennal peduncles relatively slender, narrower than opposite antennal scale, ultimate segment much longer than penultimate, both segments with a small distoventral spine; antennal scale terminating in or exceeding mid-length of, but, not reaching end of ultimate peduncular segment; flagellum composed of about 10 segments, barely reaching tip of rostrum.

Mxps 1 widely separated. Mxp 3 having ischium with distal spine lateral to rounded distal lobe on flexor face, mesial ridge with denticles rather obsolescent and much smaller on distal portion. Merus with distolateral spine and 4 distinct spines on distal half of flexor margin.

P1 more than 5 times as long as postorbital carapace length; relatively slender, covered with small spines, on merus and carpus in particular. Merus with well-developed distoventral spine and another small spine, more distinct than those elsewhere, at mid-length of ventromesial margin.

P2 with short setae on merus and carpus, less so on distal 2 segments. Merus covered with small spines, extensor marginal spines somewhat larger. Carpus spinose along extensor margin, length equal to or more than that of propodus (1.0-1.4 time as long). Flexor margin of dactylus entire. P3-4 covered with setae short on merus and carpus, long on propodus and dactylus; spinose on merus, carpus and proximal half of propodus. Dactyli massive, flexor margin with 2 distal spines pronounced and subequal, preceded by about 7 slender, inclined spines.

Eggs: Eggs carried 3-11 in number, 1.0-1.1 mm in diameter.

Remarks: The rostrum having a few distolateral spines, the antennal peduncles bearing distal segments barely spinose and the antennal scale falling short of the end of opposite ultimate segment, P1 covered with tubercular spines, and the general appearance of the carapace link the species to $U$. spinimarginatus (Henderson, 1885). However, the carapace bears a pair of epigastric spines in U. epigaster, whereas dorsally unarmed in $U$. spinimarginalus; and P3-4 dactyli bear distal two of the flexor marginal spines prominent and subequal in $U$. epigaster, whereas the penultimate is pronouncedly broader than the ultimate in U. spinimarginatus.

Etymology: The specific name is a noun in apposition from the Greek epi (on) and gaster (stomach), for the epigastric spines which are very strong in the species.

\section{Uroptychodes grandirostris (Yokoya, 1933)}

(Fig. 6)

Uroptychus grandirostris Yokoya, 1933: 68, Fig. 29 (part). van Dam, 1939: 403, Figs. 4, 4a, 5. Miyake, 1947: 735, Fig. 2125; 1965: 633, Fig. 1038. Miyake and Baba, 1967: 225, Fig. 1.

Material examined: Japan. Daio-zaki, 26 Apr. 1936, I. Kubo coll.: 1 ov. $96.1 \mathrm{~mm}$, neotype (ZLKU 4878), 1 ơ $4.3 \mathrm{~mm}$ (ZLKU 4879), 1 † $4.9 \mathrm{~mm}$ (ZLKU 4880). Tosa Bay, 29 Feb. 29 1960, K. Sakai coll.: 1 † $5.9 \mathrm{~mm}$ (ZLKU 7532). Tosa-shimizu, 28 Nov. 1958, K. Kurohara coll.: 2 † $4.0,4.4 \mathrm{~mm}$; 1 ov. क $4.3 \mathrm{~mm}, 1$ क $4.1 \mathrm{~mm}$ (ZLKU 5688). East China Sea. 1 ơ $4.8 \mathrm{~mm}, 1$ ov. क $4.4 \mathrm{~mm}$ (ZLKU 13249). [see Miyake and Baba, 1967]

Type: The ovigerous female from Daio-zaki, Japan (ZLKU 4878) is designated as a neotype.

Description: Carapace more strongly convex behind median groove. Anterior portion with small spines especially around hepatic region; one placed mesial to midpoint of hepatic lateral margin larger. Lateral margins posteriorly convex, anterolateral (first) spine moderate in size, second behind hepatic region (on anterior part of branchial region) as large as first, followed behind by distinct constriction and 5 broad, dorsoventrally depressed spines, last much smaller, often accompanying small spine behind it. Rostrum about as long as to slightly longer than remaining carapace, dorsal surface with longitudinal concavity flanked by tubercular small spines; lateral margin with 9-11 spines distal to level of cornea.

Pterygostomian flap anteriorly ending in sharp spine; surface covered with small spines.

Excavated sternum anteriorly broad triangular between Mxps 1, ridge in midline distinct. Sternite 3 having anterior margin moderately concave, bearing wide, deep excavation flanked by small incurved spine.

Abdomen spineless, with very shot, fine setae.

Eyestalks relatively wide, short, cornea visible from above.

Antennal peduncles relatively long, distal 2 segments each with strong distoventral spine, penultimate slightly shorter; flagellum consisting of 8-10 

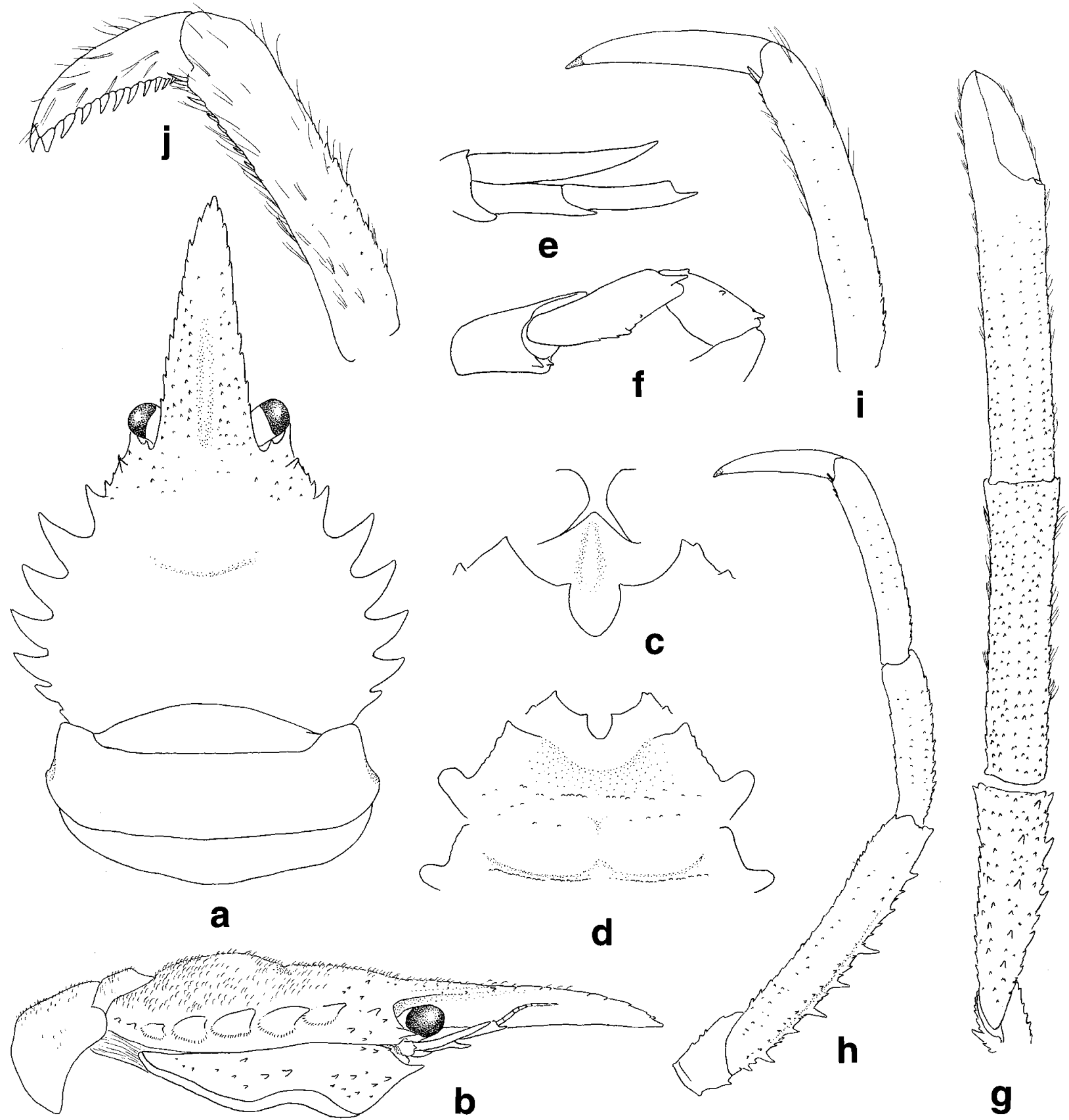

g

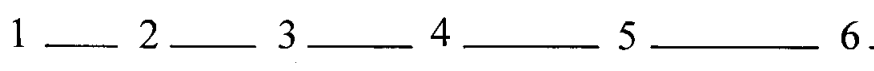

FIG. 6. - Uroptychodes grandirostris (Yokoya, 1933), ovigerous female neotype (ZLKU 4878): a, carapace and anterior part of abdomen, setae omitted, dorsal; b, same, lateral; c, excavated sternum and anterior part of sternal plastron, basal segments of Mxps 1 included, ventral; $\mathrm{d}$, anterior part of sternal plastron, ventral; e, right antennal peduncle, ventral; f, endopod of right Mxp 3, distal segments omitted, lateral; $g$, left P1, dorsal; h, left P2, lateral; i, distal segments of same; j, distal segments of left P3, lateral. Scales = $1 \mathrm{~mm}$; scale 1 for g; scale 2 for a, $\mathrm{b}$; scale 3 for $\mathrm{h}$; scale 4 for $\mathrm{d}$; scale 5 for $\mathrm{e}, \mathrm{f}, \mathrm{i}, \mathrm{j}$; scale 6 for $\mathrm{c}$.

segments; antennal scale slightly falling short of end of ultimate peduncular segment.

Mxps 1 close to each other but somewhat separated. Mxp 3 ischium with obsolescent 15-20 denticles on mesial ridge; bearing 1 or 2 spines lateral to rounded flexor distal margin. Distolateral spine well developed on merus and carpus; merus with mesial margin bearing a few to several spines often small; carpus with a few small spines somewhat lateral to extensor margin.

P1 covered with denticular small spines, moderately setose; merus with several large spines in rows. 

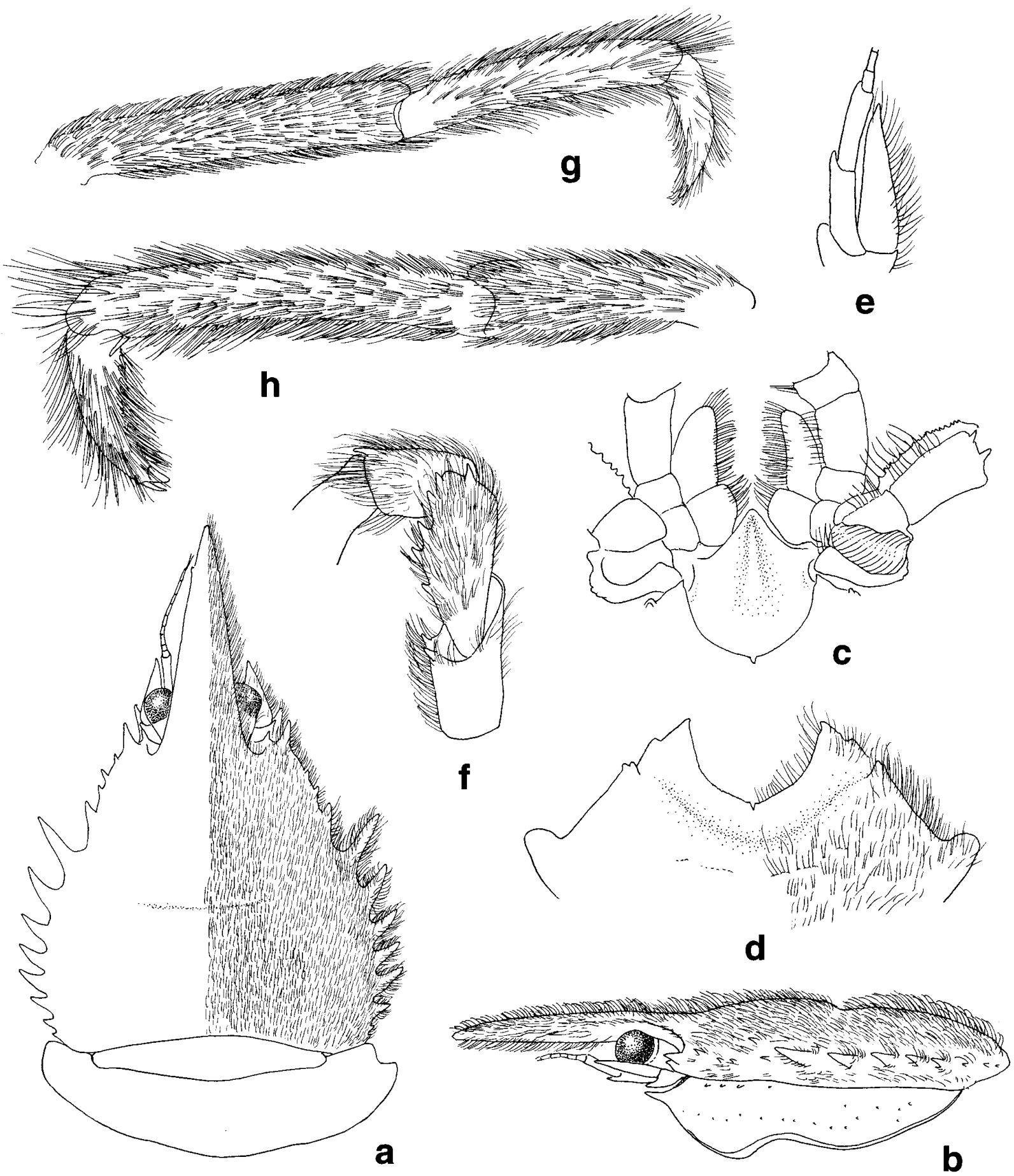

e

$1-2-3$

FIG. 7. - Uroptychodes mortenseni (van Dam, 1939), female (MNHN Ga-4172): a, carapace and anterior part of abdomen, denuded on left half of carapace and whole abdomen; b, same, abdomen omitted, lateral; c, excavated sternum and anterior part of sternal plastron, part of appendages included, ventral; d, anterior part of sternal plastron, ventral; e, left antenna, ventral; f, endopod of left Mxp 3, distal segments omitted, lateral; g, distal segments of right P2, lateral; h, distal segments of left P3, lateral. Scales = $1 \mathrm{~mm}$; scale 1 for a, b; scale 2 for d, f, $\mathrm{g}, \mathrm{h}$; scale 3 for $\mathrm{c}$, e.

P2 slender, covered with small denticular spines but rather sparse on propodus, smooth on dactylus; several spines on extensor margin of merus pronounced and widely distant from one another; car- pus about three-fourths as long as propodus; flexor margin of propodus ending in pair of spines preceded by a few smaller spines; dactylus feebly curving on flexor margin, length more than half that of 
propodus. P3-4 wider than $\mathrm{P} 2$, spinations of merus and carpus nearly same as on P2; propodus twice as long as dactylus, flexor margin ending in pair of spines preceded by at most 5 spines on $\mathrm{P} 3$, fewer on $\mathrm{P} 4$; dactylus terminating in somewhat wide, short spine, nearly contiguous at base to much wider penultimate spine preceded by 8-9 successively diminishing spines, antepenultimate nearly as large as ultimate.

Eggs: Ova carried about 35 in number, $1.0 \mathrm{~mm}$ in diameter.

Remarks: Yokoya (1933) compared his species with $U$. spinimarginatus and defined it as having narrower carapace lateral spines, as shown in his figure. As mentioned under the "Remarks" of $U$. albatrossae, the specimen (ZLKU 4881) referred to $U$. albatrossae seems to approach Yokoya's species. On the other hand, van Dam (1939) re-described one of the type material of $U$. grandirostris made available from Yokoya. However, her illustration clearly indicates much broader lateral spines on the carapace. Also the specimens reported by Miyake \& Baba (1967) from the East China Sea under $U$. grandirostris perfectly fit the description given by van Dam (1939). Examination of additional specimens listed above discloses the consistency of these broad spines, a feature of specific importance. If Yokoya's illustration is correctly depicted, the type material of $U$. grandirostris seems to contain at least two species. Unfortunately, the type is no longer extant and the specimen used by van Dam (1939) could not be located. In addition, there is no indication of locality for the material illustrated by Yokoya (1933) and for the material used by van Dam (1939). In all probability, the material illustrated under $U$. grandirostris by Yokoya (1933) will be identical with $U$. albatrossae, but there is no way to prove this. Since van Dam's account of the species is much clearer than is Yokoya's, a neotype is selected for a specimen that fits the definition of van Dam.

Other than the size difference of the lateral marginal spines of the carapace, the ultimate spine of the P2-3 dactyli is slightly narrower than or subequal to the penultimate in $U$. grandirostris, apparently slender in G. albatrossae.

\section{Uroptychodes mortenseni (van Dam, 1939)}

(Fig. 7)

Uroptychus mortenseni Van Dam, 1939: 398, Figs. 3, 3a. Baba, 1988: 38.
Lectotype: Female, ZMUC, Kai Islands Expedition Stn 52, 546'S, 13249'35”'E, 532 m (Baba, 1988: 38).

Material examined: Kai Islands, Indonesia; KARUBAR: stn CP 05, 5०49'S, 132 ${ }^{\circ} 18^{\prime} \mathrm{E}, 296-299 \mathrm{~m}, 22$ Oct. 1991: 1 \% $6.4 \mathrm{~mm}$ (MNHN Ga-4172).

Diagnosis: Body and appendages thickly covered with very fine setae obscuring spines on legs. Carapace somewhat convex in profile, with shallow groove bordering gastric and cardiac regions. Lateral margins convexly divergent posteriorly; anterolateral (first) spine well-developed, followed behind by 3 or 4 small spines on anterior third of length (last somewhat smaller than anterolateral), and again 7 or 8 posteriorly diminishing, relatively narrow spines on posterior two-thirds, anterior-most very strong, last one very small. Rostrum straight horizontal, dorsally flattened but slightly convex and spineless. Excavated sternum anteriorly triangular, extending to mid-length of basal segment of Mxp 1, surface ridged on anterior half; sternite 3 nearly semicircular on anterior margin, with small median notch. Abdomen spineless. Distal 2 segments of antennal peduncle subequal in length, with distinct distoventral spine; antennal scale much wider than adjacent peduncle, slightly falling short of end of ultimate segment, laterally setose. Mxps 1 widely separated. Mxp 3 ischium with 2 spines lateral to flexor distal margin; merus with about 5 spines on flexor margin and well-developed distolateral spine. P1 slender, merus and carpus bearing small spines obscured by setae. P2 merus with small spines along extensor and flexor margins and on dorsolateral face; carpus distinctly longer than propodus, bearing tubercle-like denticles along extensor margin; dactylus relatively short and massive, distally narrowed, about half length of propodus, flexor margin spineless. P3-4 with small spines on merus, not on carpus and propodus; dactylar flexor margin with row of spines obscured by setae, ultimate spine slender, penultimate prominent and very wide basally, preceded by slender, somewhat inclined spines.

Four longitudinal stripes on carapace continuing onto abdomen, median two much broader.

Remarks: The species is characterised by the slender pereopods, the P1 in particular, and dense pilosity on the entire body and appendages. The eyes are relatively slender in the type as well as the "Albatross" material, while the greater part of its proximal portion is concealed under the rostrum in the present specimen. 

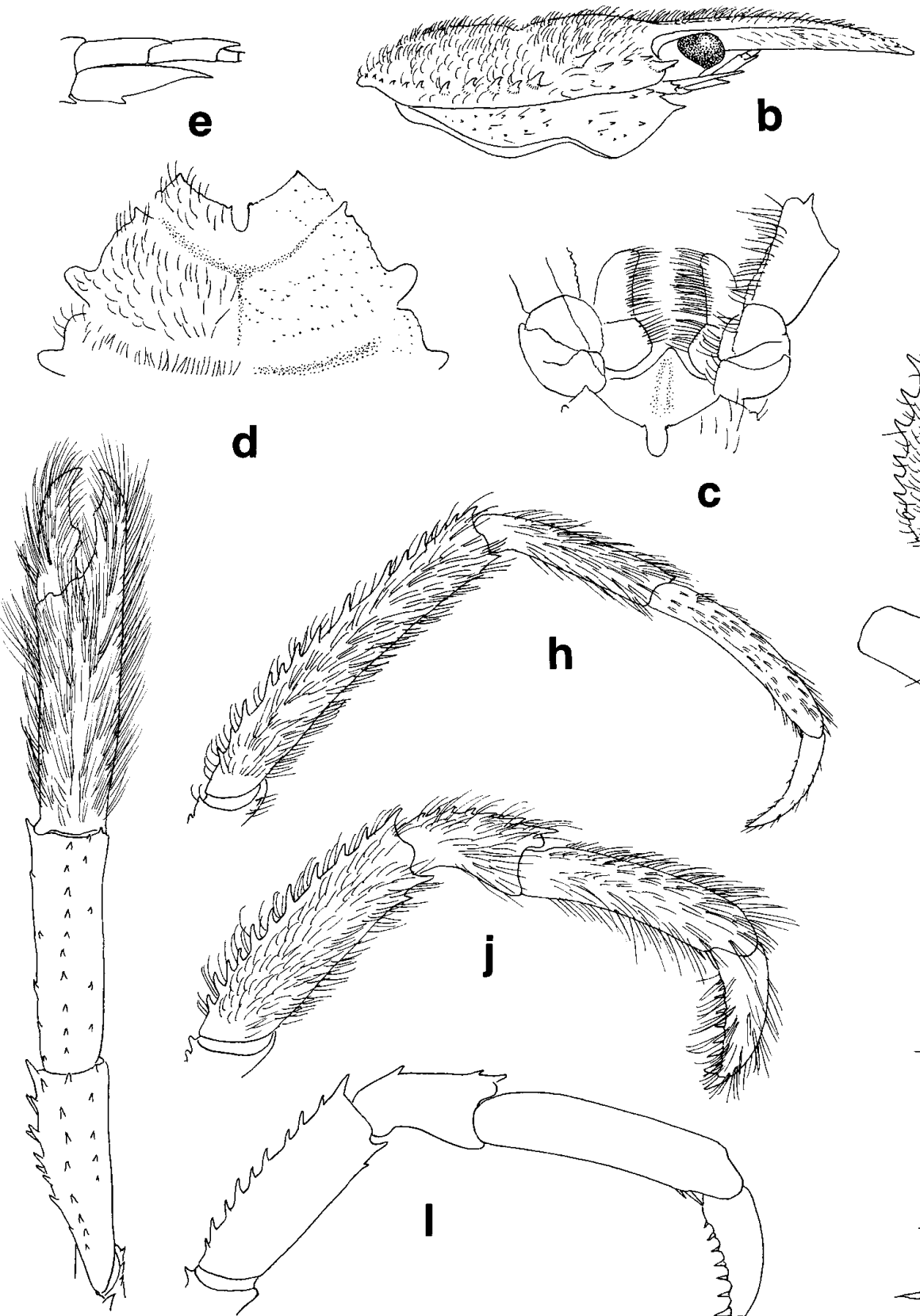

c
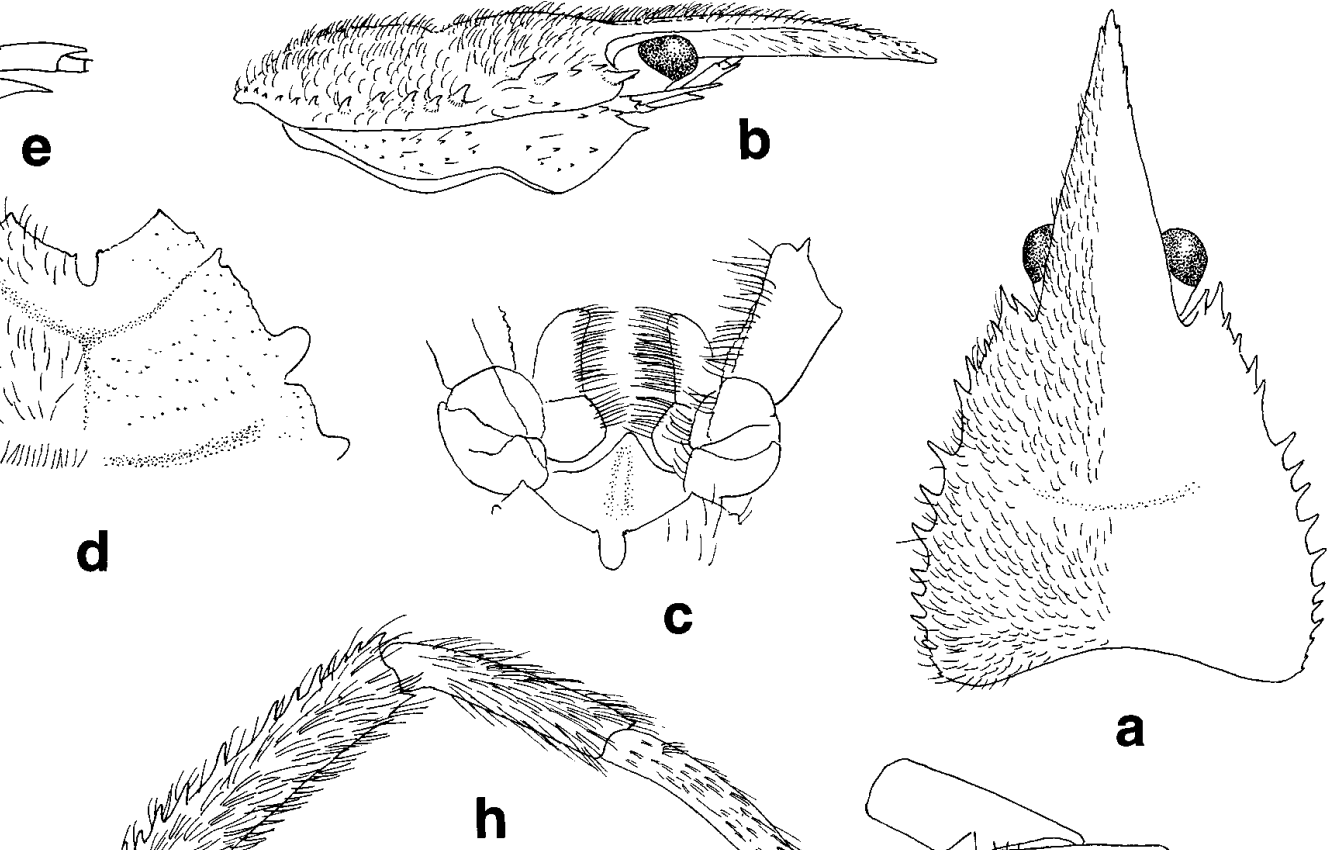

a

g
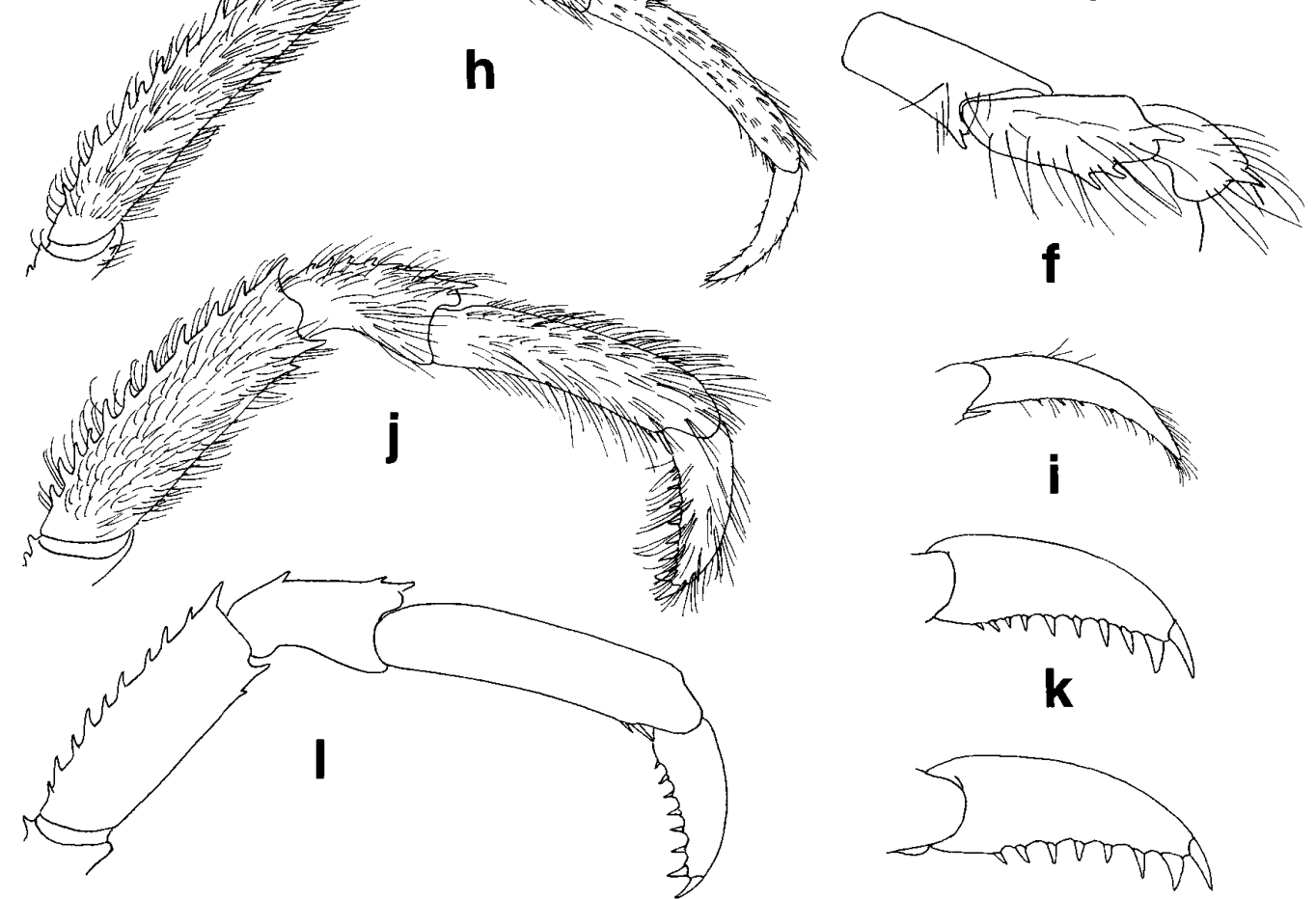

m

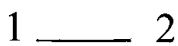

3

4

5

6

FIG. 8. - Uroptychodes musorstomi sp. nov., female holotype (MNHN Ga-4313): a, carapace, right half denuded, dorsal; b, same, lateral; c, excavated sternum and anterior part of sternal plastron, part of appendages included, ventral; d, anterior part of sternal plastron, ventral; e, left antennal peduncle, ventral; f, endopod of right Mxp 3, distal segments omitted, lateral; g, right P1, carpus and other proximal segments denuded, dorsal; h, right P2, lateral; i, distal segment of same, lateral; j, right P3, lateral; k, distal segment of same, denuded, lateral; 1 , right $\mathrm{P} 4$, denuded, lateral; $\mathrm{m}$, distal segment of same, denuded, lateral. Scales $=1 \mathrm{~mm}$; scale 1 for $\mathrm{g}$; scale 2 for a, b; scale 3 for $\mathrm{h}$, j, 1 ; scale 4 for $\mathrm{d}$; scale 5 for c; scale 6 for e, f, i, k, m.

Range: Kai Islands, Manado Bight (northeastern Sulawesi), and South China Sea off southwestern Luzon; in 250-366 m.

\section{Uroptychodes musorstomi sp. nov.}

(Fig. 8)
Material examined: Southeast New Caledonia; BIOCAL: stn CP $108,22^{\circ} 03^{\prime} \mathrm{S}, 167^{\circ} 06^{\prime} \mathrm{E}, 335 \mathrm{~m}, 9$ Sept. 1985: 1 đ $3.1 \mathrm{~mm}$ (MNHN

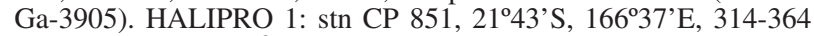
m, 19 Mar. 1994: 1 o 3.2 mm, holotype (MNHN Ga-4313).

Description: Carapace wider than long (widest portion measured at mid-length of posterior 
branchial margin), with medially deep transverse depression or groove dividing it into anterior and posterior half, covered with short fine setae. Lateral margins convexly divergent posteriorly but somewhat constricted at anterior third, armed with row of spines, anterior 5 on anterior third of length (anterior-most (first) anterolateral, fifth more dorsal in position) and another group of 6-8 posteriorly diminishing spines followed behind by a few smaller spines on posterior two-thirds; in paratype, another indistinct row of smaller and less numerous spines between normal lateral row and linea anomurica. Rostrum covered with fine setae, broad triangular, as long as remaining carapace, slightly deflexed, dorsal surface slightly excavated longitudinally; lateral margin with a few denticular spines distally. Lateral limit of orbit with anterolaterally directed spine sub-paralleling larger anterolateral spine of carapace.

Pterygostomian flap covered with small spines, anterior margin ending in strong spine.

Sternal plastron having lateral extremities convexly divergent posteriorly, but nearly sub-parallel between sternites 5 and 7. Excavated sternum anteriorly triangular, surface with distinct ridge in midline on anterior half. Elevated part of thoracic sternite 3 distinctly depressed below level of following sternite, anterior margin well excavated, with Ushaped median notch flanked by very small spine, anterolateral corner angular. Sternite 4 three times as wide as anterior margin of preceding sternite, anterolateral margin with large anterior spine directed anterolaterad.

Abdomen thickly covered with setae much longer than those on carapace, unarmed.

Eyestalks short, cornea more than half length of remaining eyestalk, partly concealed beneath rostrum.

Antennal peduncles having ultimate and penultimate segments subequal in length, each with strong distal spine; antennal scale reaching opposite end of ultimate segment excluding spine, slightly wider than peduncle, distally sharp, lateral margin with small spine somewhat proximal to mid-length (lacking on right side in holotype); flagellum consisting of 6 or 7 segments.

Mxps 1 widely separated. Mxp 3 ischium with small distal spine lateral to rounded flexor distal margin, mesial ridge with denticles reduced in size toward distal end of segment. Merus with more or less stiff setae moderate in density, with prominent distolateral spine and 2-3 close spines distal to midlength of flexor margin. Carpus with distolateral spine. Basis rounded on mesial margin bearing very small blunt tubercle at distal fourth.

P1 four times as long as postorbital carapace length; relatively massive, covered with fine setae. Merus slightly shorter than carpus in middorsal line, with about 7 rows of spines. Carpus as long as or slightly shorter than palm, dorsal surface with spines, mesial margin with line of spines. Palm distally somewhat widened. Fingers about 0.6 times as long as palm, largely or slightly gaping, distally crossing, opposable margin of fixed finger somewhat produced at point one-fifth or one-third point from distal end; opposing margin of movable finger less strongly curved, with pronounced process about at mid-length.

P2 distinctly more slender than P3-4, covered with fine setae. Merus with row of spines on extensor margin and a few smaller ones on flexor distal margin. Carpus relatively long, about half as long as merus, slightly shorter than propodus (0.82-0.86 times as long), extensor distal margin with small spine. Propodus curved, barely twice as long as dactylus; flexor margin with pair of slender distal spines. Dactylus more slender and strongly incurved than propodus, distally ending in sharp claw, lacking spines on flexor margin. P3-4 similar; meri relatively wide, bearing row of sharp spines along whole length of extensor margin and a few smaller spines on flexor distal margin. Carpi with row of spines on extensor margin. Propodus of P3 slightly shorter than that of $\mathrm{P} 4$, flexor margin with pair of slender distal spines preceded by single similar spine. Dactylus with slightly curved flexor margin armed with 8-9 (mostly 9) relatively stout spines sub-perpendicular to margin, ultimate slightly more slender and longer than penultimate, others smaller than penultimate, diminishing in size toward base of segment.

Remarks: The fewer spines on the rostral lateral margin and lack of dorsal spines on the carapace are also apparent in U. spinimarginatus (Henderson, 18885). However, the new species is distinctive in having more numerous and smaller spines on the lateral margin of the carapace, the anterolateral spine being much closer to the lateral orbital spine, the antennal peduncle having the ultimate segment with a strong distoventral spine, P2-4 dactyli bearing two well-developed distal spines and P1 bearing distinct spines on the merus and carpus.

The new species also strongly resembles $U$. okutanii Baba, 1981, from which it is distinguished by 


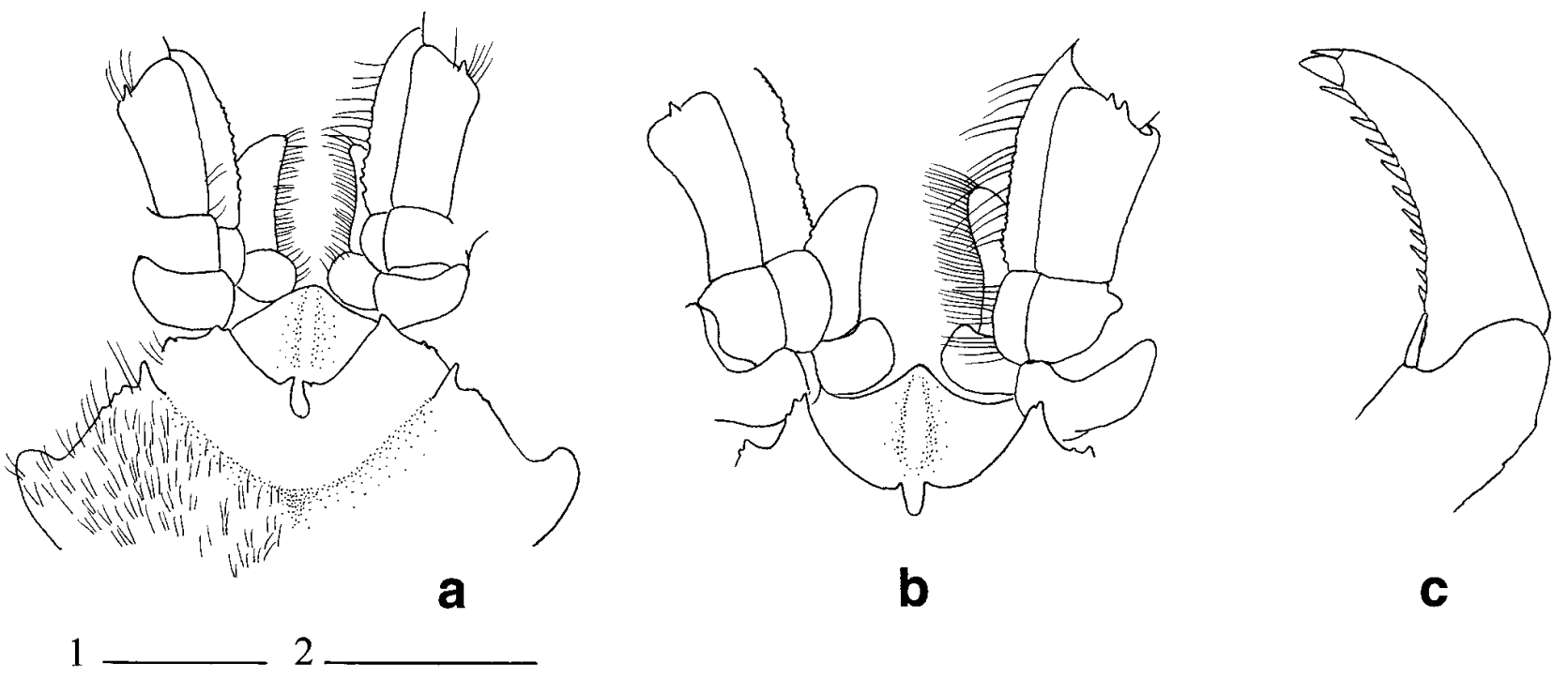

FIG. 9. - a, Uroptychodes okutanii (Baba, 1981), female holotype (NSMT-Cr 6170), excavated sternum and anterior part of sternal plastron, parts of Mxps included, ventral; b, Uroptychodes spinimarginatus (Henderson, 1885), male $6.5 \mathrm{~mm}$ (MNHN Ga-4186), same part; c, same species, ovigerous female $5.4 \mathrm{~mm}$ (MNHN Ga-4582), distal part of right P3, lateral. Scales = $1 \mathrm{~mm}$; scale 1 for b, c; scale 2 for a.

P2 dactylus that is massive and slightly curving (its basal width being slightly less than half length), instead of being very slender and strongly curving (the basal width being one-fifth length) in $U$. okutanii, Mxp 3 carpus that has a distolateral spine while no such spine in $U$. okutanii, and the excavated sternum that is sharp triangular on the anterior margin, rather than being convex in $U$. okutanii.

Etymology: Named for the past MUSORSTOM projects which yielded enormous new findings.

Uroptychodes okutanii (Baba, 1981)

(Fig. 9a)

Uroptychus okutanii Baba, 1981: 113, Figs. 2, 3.

Holotype: Female, NSMT-Cr 6170, E of Hachijo-jima, Japan, $33^{\circ} 00.5^{\prime} \mathrm{N}, 140^{\circ} 03.5^{\prime} \mathrm{E}, 510 \mathrm{~m}$.

Material examined: Female holotype, NSMT-Cr 6170.

Diagnosis: Body covered with short fine setae. Carapace lateral margins divergent posteriorly, anterolateral spine of moderate size, followed behind by 2 small spines on hepatic region, and moderatesized spines considerably inclined anteriorly (not subperpendicular to margin) on branchial region. Rostrum about as long as remaining carapace, horizontal, dorsally flattened; lateral margins almost entire or with hint of denticles distally. Excavated sternum convexly produced anteriorly, bearing ridge in midline. Sternite 3 depressed well, anterior margin deeply excavated with deep median notch flanked by small incurved spine. Sternite 4 setose, anterolateral margin relatively short, ending in relatively small spine directed anterolaterad; width less than one-third distance between anterolateral angles of sternite 3 . Abdomen spineless. Antennal peduncles with strong distoventral spine on each of distal 2 segments; flagellum consisting of 7 segments, barely reaching end of rostrum; antennal scale overreaching mid-length of but falling short of end of ultimate peduncular segment. Mxps 1 widely separated. Mxp 3 setose, ischium with small spine lateral to rounded flexor distal margin; merus with 4 small spines on distal half of flexor margin and distinct distolateral spine. P2 thickly covered with soft fine setae; carpus three-fourths as long as propodus; dactylus wide relative to length (basal width one-fifth length), slightly curving, flexor margin entire. P3-4 not known.

Remarks: The holotype was examined for characters which are missing in the original description and which are included in the diagnosis of the species (see above).

Range: Off east coast of Hachijo-jima, 455-510 m.

Uroptychodes spinimarginatus (Henderson, 1885) (Fig. 9b, c)

Diptychus spinimarginatus Henderson, 1885: 419.

Uroptychus spinimarginatus: Henderson, 1888: 176, pl. 21: Figs. 2, 2a. Baba, 1988: 46, Figs. 18, 19.

Lectotype: Ovigerous female, BM: 1888:33, "Challenger" Stn 170, off Kermadec Islands, $29^{\circ} 55^{\prime} \mathrm{S}, 178^{\circ} 14^{\prime} \mathrm{W}, 952$ m (Baba, 1988: 176). 
Material examined: Hunter and Matthew Islands; VOLSMAR: stn DW 5, 22²5.9'S, $171^{\circ} 46.5^{\prime} \mathrm{E}, 700 \mathrm{~m}, 1$ Jun. 1989: 2 ov. 우 5.3, 5.4 mm (MNHN Ga-4582); BATHUS 3: stn DW 794 23⒋'S, 16949'E, 751-755 m, 26 Nov 1993: 1 ơ $5.1 \mathrm{~mm}, 1$ ov. क $4.8 \mathrm{~mm}$ (MNHN Ga-3887). Kai Islands, Indonesia; KARUBAR: stn CP 19, $5^{\circ} 15^{\prime} \mathrm{S}, 133^{\circ} 01^{\prime} \mathrm{E}, 605-576 \mathrm{~m}$, on gorgonacean, 25 Oct. 1991: 2 ơ 5.4, $6.5 \mathrm{~mm}, 1$ ๆ $6.1 \mathrm{~mm}$ (MNHN Ga-4186).

Diagnosis: Carapace covered with fine setae, unarmed on dorsal surface; lateral margin with 5 (rarely 6) strong, somewhat anteriorly inclined spines lined up at same level in profile on posterior branchial region, preceded by moderate sized anterolateral spine followed behind by 2 small spines distinctly ventral to level of remainder, anterior one usually larger than posterior. Rostrum with 2-5 small spines on distolateral margin. Excavated sternum anteriorly broad, triangular, ending in sharp or blunt tip, surface with distinct ridge anteriorly diminishing. Abdomen unarmed. Antennal peduncles having penultimate segment with small distoventral spine, ultimate unarmed; antennal scale terminating in or slightly overreaching mid-length of adjacent ultimate segment; flagellum of 8-9 segments, barely reaching end of rostrum. Mxps 1 widely separated. Mxp 3 ischium with 1-3 small spines lateral to rounded flexor distal margin, mesial ridge with obsolescent denticles; distolateral spine on merus and carpus small or obsolescent; merus with 3 or 4 small spines on distal half of flexor margin. P1 with setiferous scale-like ridges each bearing denticular tooth on dorsal surface but often obsolescent; no pronounced spines. P2-4 very setose. P2 carpus slightly shorter than propodus even in large specimens (0.77-0.84 times as long); no distinct spine on these segments. P3-4 having meri and carpi with relatively small spines on extensor margin; propodi ending in pair of spines on flexor margin; dactyli ending in slender spine (ultimate) preceded by stout, broader penultimate and other 7-9 slender flexor marginal spines.

Eggs: Number of eggs carried, 16-20; 1.1-1.2 $\mathrm{mm}$ in diameter.

Remarks: The antennal scales in the KARUBAR material are about the same as in the "Albatross" specimen, overreaching mid-length of but falling far short of the end of the ultimate peduncular segment; the anterior median excavation is slightly wider. The specimens from Hunter and Matthew Islands are very much like the type material (Baba, 1988: 46), the anterior median notch of the sternite 3 being less pronounced or absent. No additional characters of systematic importance were noted.
Range: Off Kermadec Islands, south of the Philippines, Palawan Passage, Kai Islands, and Hunter and Matthew Islands; between 576-605 and $952 \mathrm{~m}$.

\section{Uroptychodes spinulifer (van Dam, 1940)}

(Fig. 10)

Uroptychus spinulifer Van Dam, 1940: 100, Fig. 3. Baba, 1988: 48, Fig. 20.

Holotype: Female, ZMA De. 101.669, Java Sea, 5³9’ S, 111¹9’ E, 68-71 m.

Material examined: Kai Islands, Indonesia; KARUBAR: stn CP 16, $5^{\circ} 17^{\prime} \mathrm{S}, 132^{\circ} 50$ 'E, 315-349 m, on crinoid, 24 Oct. 1991: 1 \% 5.6 mm (MNHN Ga-4185).

Diagnosis: Carapace and rostrum (even on ventral surface) covered with small spines and short, relatively stiff setae. Anterolateral spine of carapace sharp and moderate in size, curving somewhat anterolaterad, close to and sub-paralleling lateral orbital spine; 6 or 7 strong spines on branchial margin. Rostrum much longer than remaining carapace, spinose like carapace, lateral margin with more than 10 small spines. Excavated sternum anteriorly triangular, sharply produced forward, surface cristate in midline; sternite 3 having anterior margin widely U-shaped, with deep median notch flanked by small spine. Abdominal somites 1 and 2 with small spines. Antennal peduncles having distal 2 segments with unusually strong distoventral spine, one on penultimate segment in particular, and even mesial marginal spines; antennal scale overreaching opposite end of peduncle, bearing lateral spines. Mxps 1 nearly contiguous at base. Mxps 3 also very spinose on merus and carpus; ischium with well-developed distal spine lateral to rounded distal margin of flexor margin; merus and carpus each with strong distolateral spine; sharp spines on flexor margin of merus and extensor margin of carpus. P2 covered with sharp, somewhat curved spines; carpus much longer than propodus; propodus less spinose; dactylus spineless. P4 covered with spines, those on meri and carpi much pronounced on extensor margins, less so on flexor margin; propodus with flexor margin ending in pair of spines; dactylar flexor margin having wide and stout penultimate spine preceded by 6 slender spines, ultimate somewhat larger than antepenultimate.

Remarks: In the specimen examined, P1 and P3 are missing; $\mathrm{P} 4$ is more strongly and numerously 

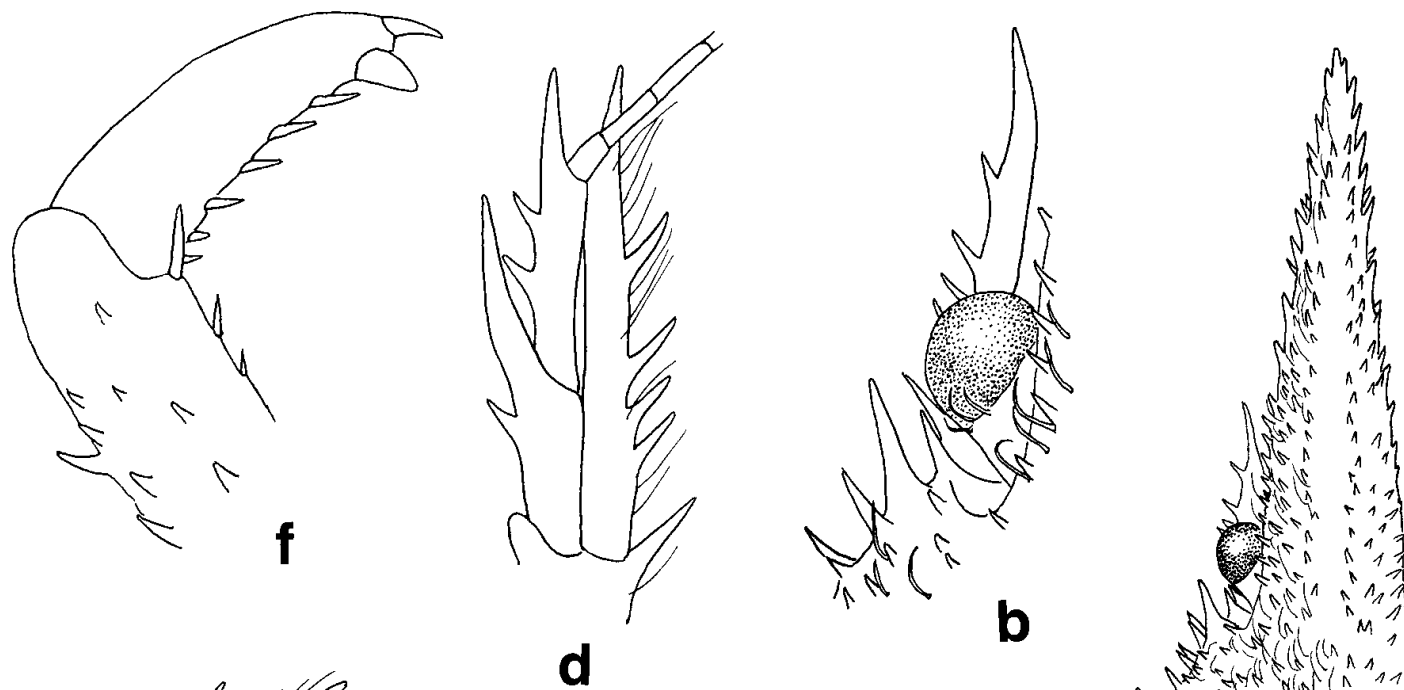
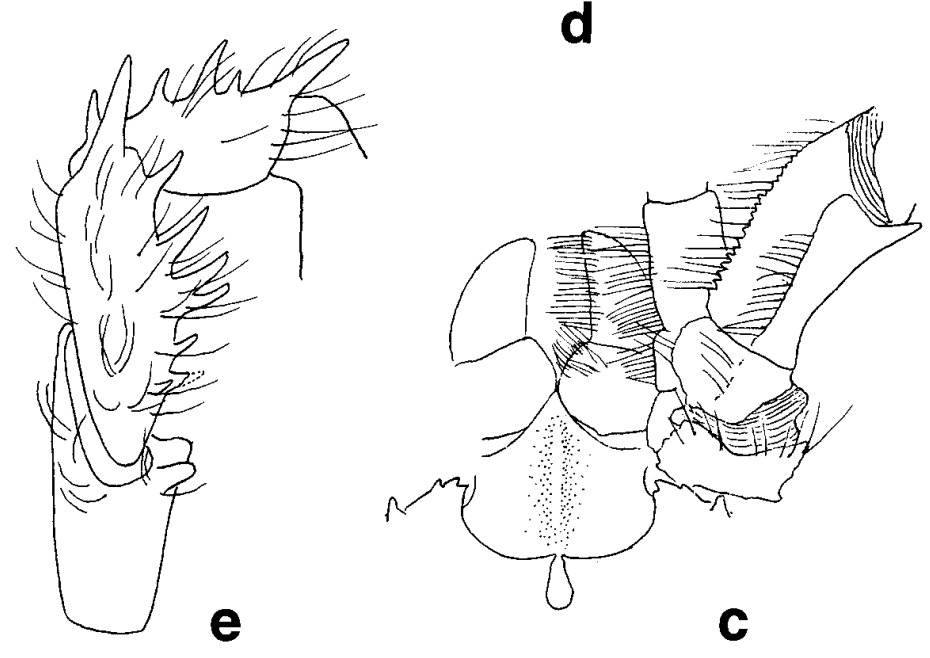

3

4

\section{$1-2$}

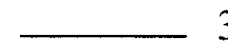

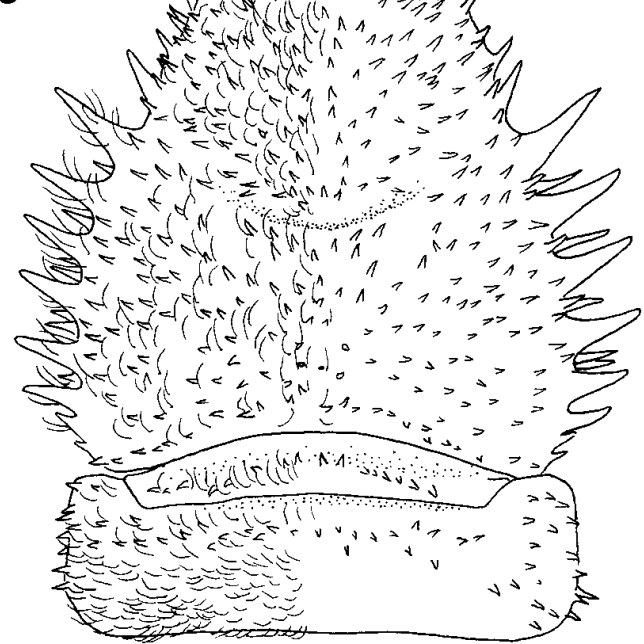

a

FIG. 10. - Uroptychus spinulifer (van Dam, 1940), female (MNHN Ga-4185): a, carapace and anterior part of abdomen, dorsal, setae omitted from left half; $b$, anterolateral part of carapace, showing lateral limit of orbit, left, dorsal; c, excavated sternum and anterior part of sternal plastron, parts of Mxps included, ventral; d, left antenna, ventral; e, endopod of right Mxp 3, distal segments omitted, lateral; f, distal part of right $\mathrm{P} 4$, lateral. Scales $=1 \mathrm{~mm}$; scale 1 for $\mathrm{a}$; scale 2 for $\mathrm{b}$; scale 3 for c, e; scale 4 for $\mathrm{d}, \mathrm{f}$.

spinous than in the type and "Albatross" material; the antennal spination is also much more pronounced (the distoventral spines of the distal two segments are stronger, that of the penultimate segment in particular); extra lateral marginal spines on the antennal scale; $\mathrm{P} 2$ has the propodus much shorter than the carpus.

The specimen examined was associated with an unidentified crinoid, a case being very rare among chirostylids, which are usually symbionts of gorgonacean or antipatharian corals. The only available record for crinoid-chirostylid association is Uroptychus capillatus Benedict, 1902 and a comatulid Crinometra brevipinna (Pourtalès) from Bahamas (Rice and Miller, 1991).
Range: Java Sea and Molucca Sea off west coast of Halmahera, between 68-71 m and 315-349 m.

\section{Key to species of Uroptychodes}

1. Carapace covered with denticles or small spines

- Carapace dorsally spineless or bearing denticular spines on anterior portion

2. Abdominal segments unarmed; excavated sternum produced forward, reaching end of Mxp 1 basal segment ........ U. benedicti (Baba, 1977)

- Abdominal segments 1-2 with small spines; excavated sternum sharp triangular, terminating in mid-length of Mxp 1 basal segment 
U. spinulifer (van Dam, 1940)

3. Rostral lateral margin with more than 5 small spines

- Rostral lateral margin with a few denticular spines distally or nearly smooth

4. Rostrum having lateral margin with 5-6 small spines, dorsal surface lacking denticles

U. barunae sp. nov.

- Rostrum having lateral margin with more than 9 small spines, dorsal surface with numerous denticles 5

5. Branchial marginal spines of carapace very broad (basal width of largest spine two-thirds length), nearly contiguous to one another at base

U. grandirostris (Yokoya, 1933)

- Branchial marginal spines of carapace slender (basal width of largest spine distinctly less than half length), separated from one another by their basal width .......... U. albatrossae (Baba, 1988)

6. Carapace with spine behind lateral orbital spine (on lateral portion of anterior gastric region) ..... U. epigaster $\mathrm{sp}$. nov.

- Carapace spineless on dorsal surface .. 7

7. P2 carpus distinctly longer than propodus U. mortenseni (van Dam, 1939)

- P2 carpus slightly shorter than propodus ........ 8

8. Branchial marginal spines 5 in number, very strong .... U. spinimarginatus (Henderson, 1885)

- Branchial marginal spines 8-9 in number, very small 9

9. P2 dactylus wide relative to length (basal width slightly less than half length); excavated sternum convexly produced anteriorly between left and right Mxps 1; Mxp 3 carpus lacking distolateral spine U. okutanii (Baba, 1981)

- P2 dactylus very slender (basal width one-fifth length); excavated sternum sharp triangular between left and right Mxps 1; Mxp 3 carpus with distinct distolateral spine U. musorstomi $\mathrm{sp}$. nov.

\section{ACKNOWLEDGMENTS}

I thank Alain Crosnier of the Muséum National d'Histoire Naturelle, Paris, for his help and support. Thanks are also due to Paul Clark of the Natural History Museum, London, Rafael Lemaitre of the Smithsonian Institution, Washington, D.C., Masatsune Takeda of the National Science Museum, Tokyo, and Kyoichiro Ueda of the Kitakyushu Museum of Natural History, Kitakyushu, for loans of type and comparative materials in their respective institutions. The manuscript benefited from discussions with A. Crosnier and constructive comments from Enrique Macpherson of the Centro de Estudios Avanzados de Blanes, Gerona. The English text was read by Colin L. McLay of the University of Canterbury, Christchurch. This work, part of the MUSORSTOM projects, was carried out during my visits to the Laboratoire de Biologie des Invertebrés marins et Malacologie, Muséum National d'Histoire Naturelle, Paris, supported by grants from the Institut de Recherche pour le Développement in 1998 and 1999, and from the Muséum National d'Histoire Naturelle in 2000 and 2001.

\section{REFERENCES}

Baba, K. - 1977. A new species of Uroptychus (Crustacea, Anomura, Chirostylidae) from off Honshu, Japan. Annot. zool. jap. 50(2): 123-126

Baba, K. - 1981. Deep-sea galatheidean Crustacea (Decapoda, Anomura) taken by the R/V Soyo-Maru in Japanese waters. I. Family Chirostylidae. Bull. natl. Sci. Mus., Tokyo, (A - Zool.), 7(3): 111-134.

Baba, K. - 1988. Chirostylid and galatheid crustaceans (Decapoda: Anomura) of the "Albatross" Philippine Expedition, 19071910. Res. Crust., Special Number 2: v + 203 pp.

Baba, K. - 1990. Chirostylid and galatheid crustaceans of Madagascar (Decapoda, Anomura). Bull. Mus. natn. Hist. nat., Paris, $4^{\mathrm{e}}$ ser., 11 (1989), sec. A, no. 4: 921-975.

Balss, H. - 1957. Decapoda. In: Dr. H. G. Bronns Klassen und Ordnungen des Tierreichs, 5(1)7: 1505-1672. Leipzig: Akademische Verlagsgesellschaft Geest \& Portig K.-G.

Benedict, J.E. - 1902. Descriptions of a new genus and forty-six new species of crustaceans of the family Galatheidae, with a list of the known marine species. Proc. U. S. natn. Mus., 26: 243-334.

Crosnier, A, B. Richer de Forges, and P. Bouchet. - 1997. La campagne KARUBAR en Indonésie, au large des îles Kai et Tanimbar. In: A. Crosnier and P. Bouchet (eds.), Résultats des campagnes MUSORSTOM, Volume 16. Mém. Mus. natn. Hist. nat., 172: 9-26.

van Dam, A.J. - 1933. Die Decapoden der Siboga-Expedition. VIII. Galatheidea: Chirostylidae. Siboga-Exped., Monogr. $39 a^{7}: 1-46$.

van Dam, A.J. - 1939. Ueber einige Uroptychus-Arten des Museums zu Kopenhagen. Bijdr. Dierk., 27: 392-407.

van Dam, A.J. - 1940. Anomura, gesammelt vom Dampfer "Gier" in der Java-See. Zool. Anz., 129: 95-104.

Henderson, J.R. - 1885. Diagnoses of the new species of Galatheidea collected during the Expedition. Ann. Mag. nat. Hist., (5)16: 407-421.

Henderson, J.R. - 1888. Report on the Anomura Collected by H.M.S. Challenger during the Years 1873-76. Rep. sci. Res. Voy. Challenger, Zool., 27: vi + 221 pages, 21 pls.

McLaughlin, P.A. - 1980. Comparative Morphology of Recent Crustacea. W.H. Freeman \& Co., San Francisco.

Miyake, S. - 1947. Crustacea, Anomura. In: Uchida, S., Illustrated Encyclopedia of the Fauna of Japan (Exclusive of Insects), Revised Edition, pp. 731-750, Figs. 2115-2171. Tokyo: Hokuryukan.

Miyake, S. - 1965. Crustacea, Anomura. In: Okada, Y.K., S. Uchida and T. Uchida, New Illustrated Encyclopedia of the Fauna of Japan, 2: 630-652. Tokyo.

Miyake, S. and K. Baba. - 1967. Galatheids of the East China Sea (Chirostylidae and Galatheidae, Decapoda, Crustacea). J. Fac. Agr., Kyushu Univ., 14(2): 225-246.

Rice, A.L. and J.E. Miller. - 1991. Chirostylid and galatheid crustaceans associates of coelenterates and echinoderms col- 
lected from the Johnson-Sea-Link submersible, including a new species of Gastroptychus. Proc. biol. Soc. Wash., 104(2): 299-308.

Richer de Forges, B. - 1990. Les campagnes d'exploration de la faune bathyale dans la zone conomique de la Nouvelle-Calédonie. In: A. Crosnier (ed.), Résultats des Campagnes MUSORSTOM, Volume 6. Mém. Mus. Natn. Hist. Nat., (A), 145: 9-54

Richer de Forges, B. - 1993. Campagnes d'exploration de la faune bathyale faites depuis mai 1989 dans la zone économique de la Nouvelle-Calédonie. Listes des stations. Mém. Mus. Natn. Hist. Nat., 156: 27-32.
Richer de Forges, B. and C. Chevillon. - 1996. Les campagnes d'échantillonnage du benthos bathyal en Nouvelle-Calédonie, en 1993 et 1994 (BATHUS 1 à 4, SMIB 8 et HALIPRO 1). Mém. Mus. Natn. Hist. Nat., 168: 33-53.

Tirmizi, N.M. - 1964. Crustacea: Chirostylidae (Galatheidea). Scient. Rep. John Murray Exp., 10(8): 385-415.

Yokoya, Y. - 1933. On the distribution of decapod crustaceans inhabiting the continental shelf around Japan, chiefly based upon the materials collected by S.S. Soyo-Maru during the years 1923-30. J. Coll. Agr., Tokyo Imp Univ., 12(1): 1-226.

Scient. ed.: E. Macpherson 